A contribution of the National Water-Quality Assessment Program

\title{
Stream and Aquifer Biology of South-Central Texas-A Literature Review, 1973-97
}

Open-File Reportog-243

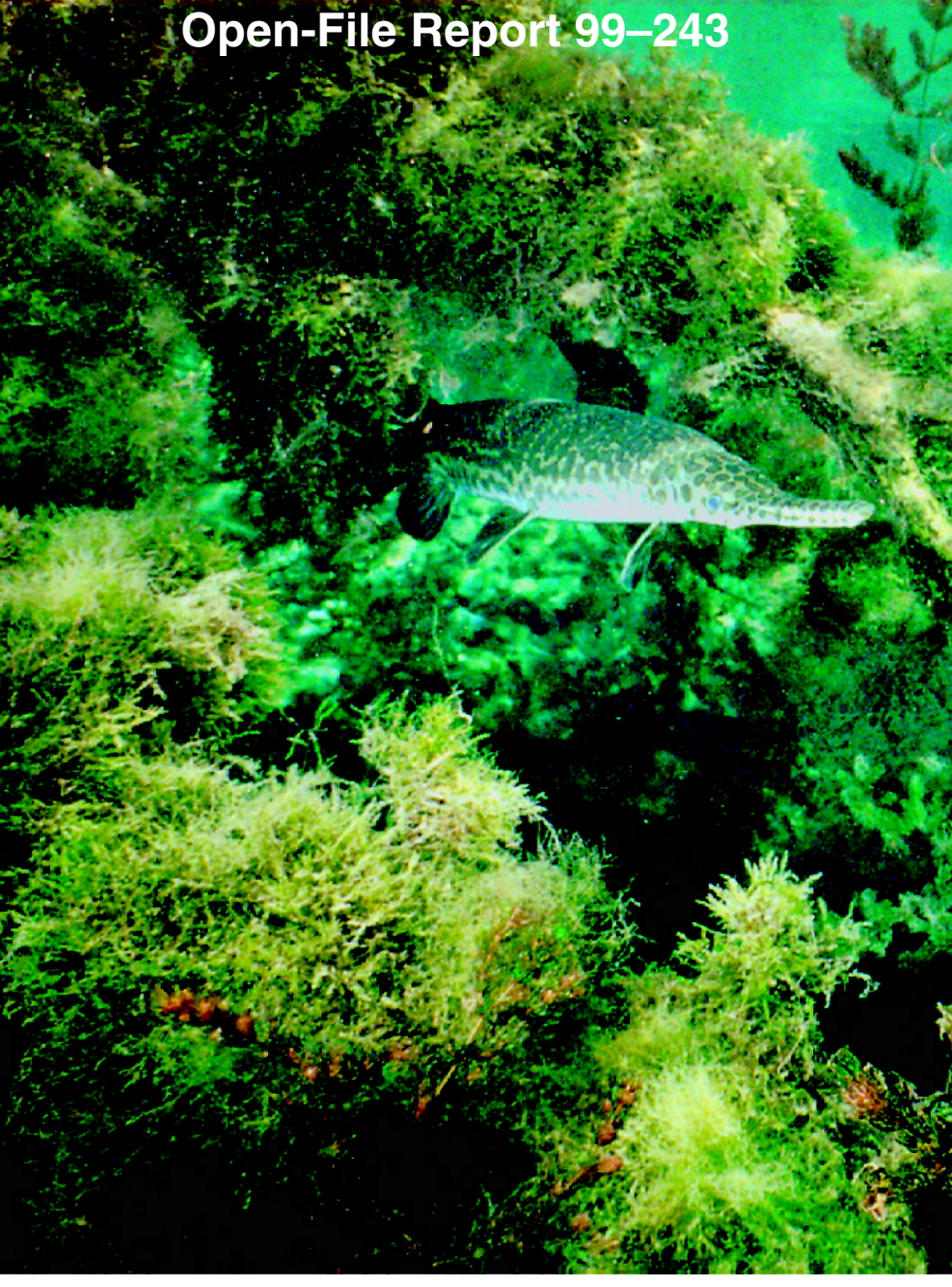

U.S. Department of the Interior U.S. Geological Survey 


\section{Cover:}

Spotted gar in San Marcos Springs. (Photograph by Dan Misiaszek, San Marcos Area Recovery Team.) 
U.S. Department of the Interior

U.S. Geological Survey

\title{
Stream and Aquifer Biology of South-Central Texas-A Literature Review, 1973-97
}

By Robert T. Ourso and C. Evan Hornig

\author{
U.S. GEOLOGICAL SURVEY \\ Open-File Report 99-243
}

A contribution of the National-Water Quality Assessment Program

Austin, Texas

2000 


\section{U.S. DEPARTMENT OF THE INTERIOR}

Bruce Babbitt, Secretary

\section{U.S. GEOLOGICAL SURVEY}

Charles G. Groat, Director

Any use of trade, product, or firm names is for descriptive purposes only and does not imply endorsement by the U.S. Government.

For additional information write to

\section{District Chief}

U.S. Geological Survey

8027 Exchange Dr.

Austin, TX 78754-4733

E-mail: dc_tx@usgs.gov

Copies of this report can be purchased from

U.S. Geological Survey

Branch of Information Services

Box 25286

Denver, CO 80225-0286

E-mail: infoservices@usgs.gov 


\section{CONTENTS}

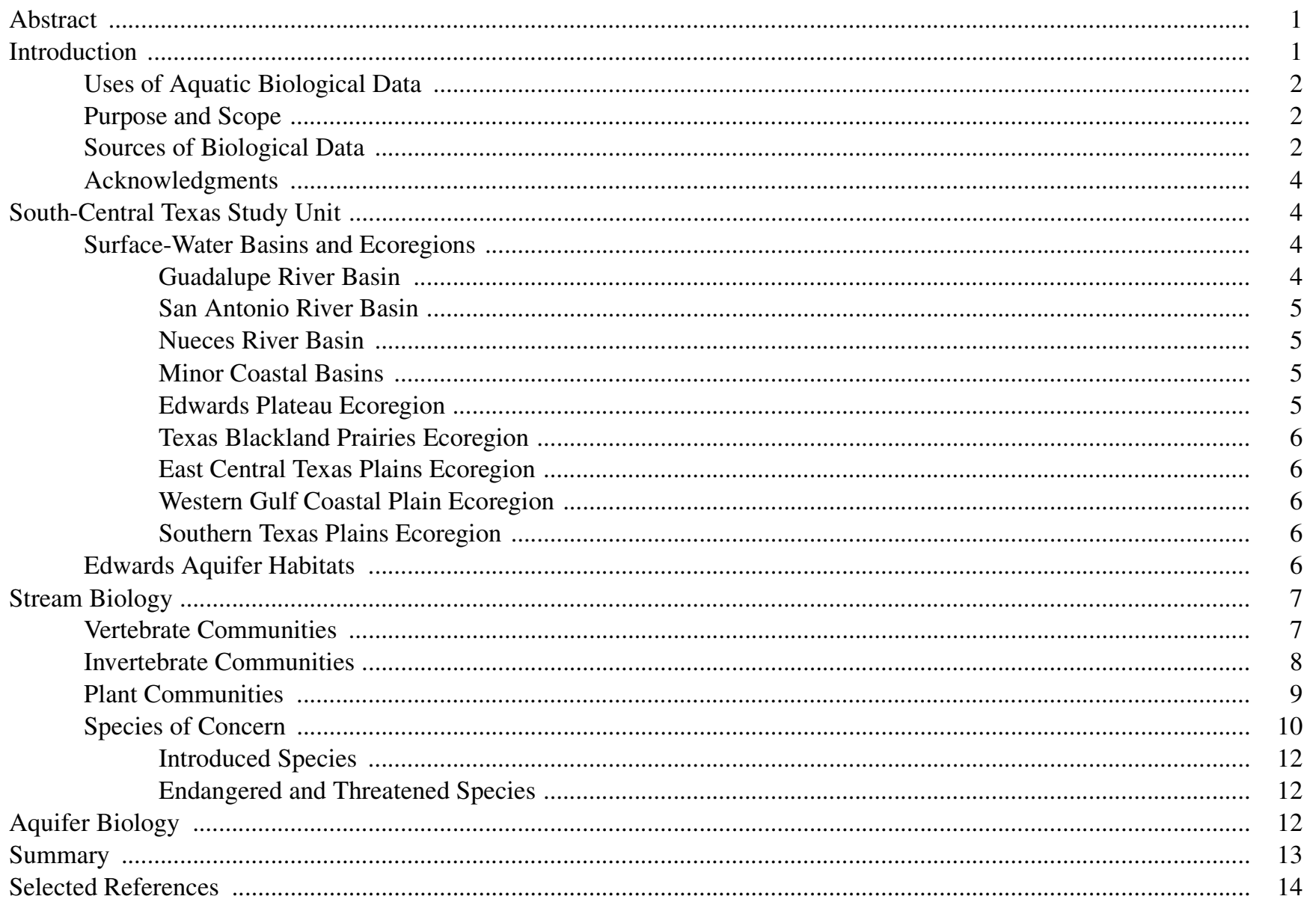

\section{FIGURES}

1-5. Maps showing:

1. Surface-water basins, ecoregions, and major aquifers of the South-Central Texas study unit, Texas ....... 3

2. Locations of previous fish studies in the South-Central Texas study unit, Texas ..................................... 8

3. Locations of previous fish studies in Bexar, Comal, and Hays Counties, Texas .................................... 9

4. Locations of previous aquatic invertebrate studies in the South-Central Texas study unit, Texas ............ 10

5. Locations of previous aquatic invertebrate studies in Bexar, Comal, and Hays Counties, Texas ............. 11

\section{TABLES}

1. Literature citations for biological surveys and field studies in the South-Central Texas study unit, Texas

2. Fish collected in streams of the South-Central Texas study unit, Texas .......................................................... 27

3. Aquatic invertebrates collected in streams of the South-Central Texas study unit, Texas ................................ 31

4. Aquatic macrophytes in aquatic habitats of the South-Central Texas study unit, Texas ................................... 36

5. Non-native species in aquatic habitats of the South-Central Texas study unit, Texas ..................................... 36

6. Federal and State listed endangered and threatened species in aquatic habitats of the South-Central Texas study unit, Texas

7. Troglobitic species of the Edwards aquifer in the South-Central Texas study unit, Texas ……....................... 38 


\section{VERTICAL DATUM}

Sea level: In this report, "sea level" refers to the National Geodetic Vertical Datum of 1929-a geodetic datum derived from a general adjustment of the first-order level nets of both the United States and Canada, formerly called Sea Level Datum of 1929. 


\title{
Stream and Aquifer Biology of South-Central Texas-A Literature Review, 1973-97
}

\author{
By Robert T. Ourso and C. Evan Hornig
}

\begin{abstract}
This report summarizes in table format 32 aquatic vertebrate (primarily fish), 54 aquatic invertebrate, and 13 aquatic plant studies available for the area of the South-Central Texas study unit of the U.S. Geological Survey National WaterQuality Assessment. The studies, published mostly during 1973-97, pertain to the Guadalupe, San Antonio, and Nueces River Basins, the San Antonio-Nueces and Nueces-Rio Grande Coastal Basins, and the Edwards aquifer where it underlies the upper parts of the three river basins. The biology of the study-unit streams is determined mostly by the characteristics of the ecoregions they transect-the Edwards Plateau, Texas Blackland Prairies, East Central Texas Plains, Western Gulf Coastal Plain, and Southern Texas Plains.
\end{abstract}

About 20 percent of the previous fish and invertebrate studies and about 75 percent of the aquatic plant surveys have centered on Comal Springs in Comal County and San Marcos Springs in Hays County. Although several important studies are available for the San Antonio region, documentation of aquatic biology for the remainder of the study unit is relatively sparse. The streams in the study unit, particularly in the Edwards Plateau, support three dominant biological groups-fish, aquatic invertebrates, and plants. Potential threats to these organisms include impoundments and flood-control projects, siltation from erosion, ground-water pumping, recreational activities, wastewater discharge, and introduction of nonnative species. More than 30 non-native fish, invertebrate, and plant species have been introduced into the region. Of the 19 aquatic species Federally listed as endangered or threatened in Texas, 8 are associated with springs and spring runs in the study unit. All of the endangered species in the study unit are associated with springs and spring runs.

A large number of endemic species in the study unit are associated with subterranean aquatic ecosystems, most likely a consequence of the unique proximity of the varied topographic and hydrologic conditions of the area and of the geological development of the Edwards aquifer. Ninety-one endemics, including 44 species found solely underground, are associated with the aquatic ecosystems (including springs) of the Edwards aquifer.

\section{INTRODUCTION}

The U.S. Geological Survey (USGS) National Water-Quality Assessment (NAWQA) Program began in 1991 to assess many of the Nation's major river basins and aquifers. The Program is designed to produce technically sound descriptions regarding the status of and the trends in the resource quality of these aquatic systems. NAWQA also is designed to increase the understanding of the natural and human factors that affect these water resources and to link this understanding with the observed status and trends. The nationally consistent, integrated assessment of chemical, physical, and biological resources will provide water managers and policy makers with information for directing waterquality management programs and for evaluating the effectiveness of these programs. Gilliom and others (1995) present a complete description of the NAWQA objectives and design.

The building blocks of the NAWQA Program are study-unit investigations. The study units selected encompass one or more major river basins and aquifers. When fully implemented, there will be more than 50 study units distributed across the Nation. Combined, they encompass about one-half of the conterminous United States and 60 to 70 percent of the population and national water use. One-third of the study units are intensively studied for 3 years on a rotational basis 
with each of the other two groups of study units, resulting in each study unit being revisited for intensive study on 9-year cycles. The NAWQA study unit addressed in this report is the South-Central Texas (SCTX) study unit (fig. 1), which includes the Guadalupe, San Antonio, and Nueces River Basins; two minor coastal basins; and the Trinity, Edwards, Carrizo-Wilcox, and Gulf Coast aquifers where they underlie the three river basins.

In addition to intensive field investigations, retrospective reports of existing environmental data are prepared at study-unit and national levels to improve the understanding of historical and present conditions of the water resources and to help interpret results from the intensive field investigations. Retrospective synthesis of existing stream and aquifer biological data for the SCTX study unit is addressed in this report.

\section{Uses of Aquatic Biological Data}

Biological monitoring is widely used to assess water resources, both as an integrative assessment tool and as the only direct method to determine instream attainment of State water-quality standards for aquatic life use. These standards are assigned to most U.S. surface waters. To determine instream attainment of these standards, some states have incorporated biological criteria into State water-quality criteria and regulations (Davis and others, 1996). These criteria are either narrative descriptions, such as lists of fish species, or numerical expressions (metrics) of aquatic life variables, including diversity indices and pollution tolerance values (U.S. Environmental Protection Agency, 1996).

Biological monitoring serves as an integrative assessment tool in two ways: (1) The type and condition of organisms reflect the overall health of the aquatic resources (Karr, 1995), and (2) the relatively stationary nature of many aquatic organisms signifies their ability to integrate environmental conditions over time, thereby reducing frequency of sampling needed to detect changes (Hynes, 1960).

Combining biological monitoring with physical and chemical data can be used to develop a comprehensive and efficient approach to water-quality surveillance (Hornig, 1984). Initial surveys of one or more components of the resident biota (typically fish, invertebrates, or plants) provide evaluations of the overall quality of the water resources. When results from these initial surveys indicate biological impairment, follow-up analyses (chemical, habitat, or more intensive biological studies) are done to determine the extent and probable causes. Biological monitoring also can be used to measure the success of restoration and the subsequent attainment of water-quality standards.

Reference-site or paired-site monitoring helps factor out annual area-wide variations in the biota, improving the ability to distinguish localized (typically human-caused) effects from regional (typically climatic) effects. Reference sites are the least impaired sites in a specific geographic region and serve as "benchmarks" for evaluating the stream quality at other sites. State water-quality agencies use biological data at reference sites to develop the biological criteria used to determine attainment of water-quality standards for aquatic life use (Hornig and others, 1995).

The USGS recognizes the critical role of biological and habitat data for comprehensive assessment of aquatic environments by water-resource managers. When complemented with chemical constituent data and land use information, biological and habitat data can be useful for identifying the natural and human factors affecting current conditions and the trends in aquatic-resource quality (Cuffney and others, 1997).

\section{Purpose and Scope}

This retrospective report summarizes information on aquatic biology of the streams and rivers in the Guadalupe, San Antonio, and Nueces River Basins and the San Antonio-Nueces and Nueces-Rio Grande Coastal Basins, and of the Edwards aquifer where it underlies the three river basins. (Aquatic biological information on the Trinity, Carrizo-Wilcox, and Gulf Coast aquifers is not included.) The report contains lists and distributions of fish and aquatic invertebrates, and lists of aquatic plants, aquifer organisms, non-native aquatic species, and endangered aquatic species. The report identifies sources of information on the biology of the streams and rivers and of the aquifer. Maps are provided to identify studies in specific areas. The report summarizes major publications, serving as a "one-stop" resource for historical aquatic biological data (prior to 1998) for this region.

\section{Sources of Biological Data}

Primarily Federal, State, and academic organizations have collected biological data from river basins in the SCTX study unit. The studies and reports of the U.S. Fish and Wildlife Service (USFWS), Texas Natural 


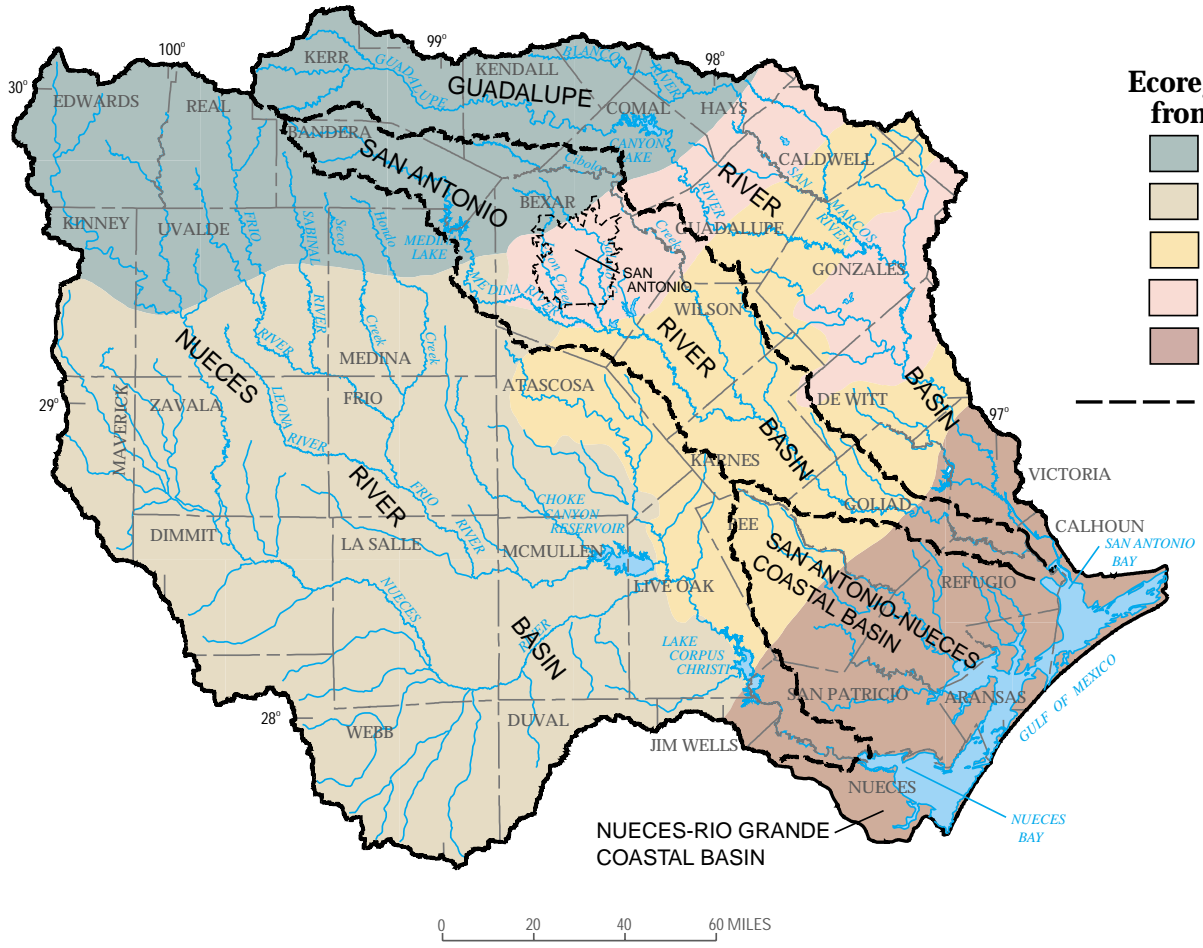

\section{EXPLANATION}

Ecoregions (Modified from Omernik, 1987)

Edwards Plateau

Southern Texas Plains

East Central Texas Plains

Texas Blackland Prairies

Western Gulf Coastal Plain

\section{Basin boundary}

\section{EXPLANATION}

Major aquifers (Modified from Ashworth and Hopkins, 1995)

\section{Gulf Coast}

Outcrop $\square$ Edwards-Subcrop Subcrop

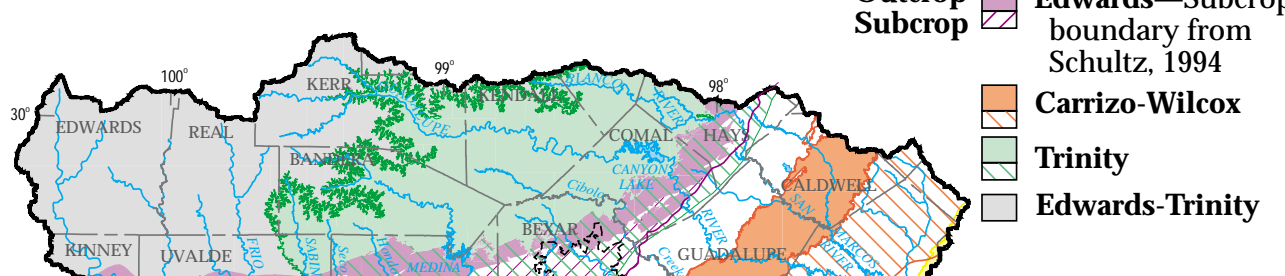

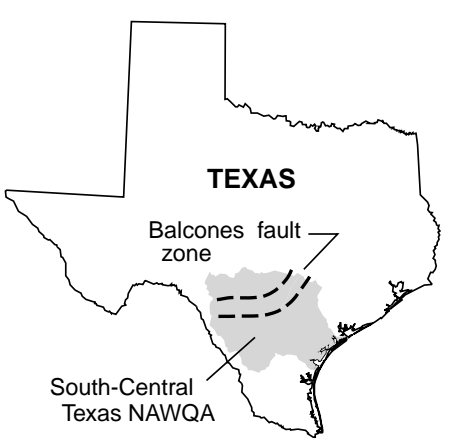

LOCATION MAP

Figure 1. Surface-water basins, ecoregions, and major aquifers of the South-Central Texas study unit, Texas. 
Resource Conservation Commission (TNRCC), Texas Parks and Wildlife Department (TPWD), San Antonio River Authority, Southwest Texas State University, and University of Texas provide most of the information in this report. This report emphasizes biological surveys that mostly were published after 1972. Young and others (1973) provide a compilation of information collected prior to 1973 .

\section{Acknowledgments}

The authors thank their colleagues at the U.S. Fish and Wildlife Service, Texas Natural Resource Conservation Commission, Texas Department of Parks and Wildlife, San Antonio River Authority, Southwest Texas State University, and University of Texas, who have been instrumental in providing literature and biological data cited in this report.

\section{SOUTH-CENTRAL TEXAS STUDY UNIT}

The SCTX study unit is located in south-central Texas, encompassing the Guadalupe, San Antonio, and Nueces River Basins, two minor coastal basins, and the Trinity, Edwards, Carrizo-Wilcox, and Gulf Coast aquifers where they underlie the three river basins (fig. 1). This region of Texas contains a diversity of both surface-water and aquifer habitats. In addition to lakes and streams of various sizes and geomorphic types, the Edwards aquifer and associated springs provide habitat to a variety of unique aquatic species.

\section{Surface-Water Basins and Ecoregions}

The SCTX study unit, with a drainage area of about 30,000 square miles ( $\left.\mathrm{mi}^{2}\right)$, encompasses parts of five ecoregions (fig. 1). The ecoregions, as described by Omernik (1987), are the Edwards Plateau, Texas Blackland Prairies, East Central Texas Plains, Western Gulf Coastal Plain, and Southern Texas Plains. The study unit has a wide variety of climatic, geologic, topographic, and hydrologic conditions. The proximity of ecoregions with different characteristics (fig. 1) makes the study unit a "convergent zone" of soil, climatic, topographic, and biotic features. Detailed descriptions of the flora, fauna, and land use are in Blair (1950) and Gould (1975).

The biology of the study-unit streams is determined mostly by the characteristics of the ecoregions they transect. Aquatic life is similar in the upper reaches of each of the three major river basins, as these reaches are within the Edwards Plateau ecoregion. The mostly spring-fed streams in this ecoregion have stable bottom substrates, well-vegetated streambanks, and cool, clear water year round. Invertebrate taxa richness and other measures of aquatic life health used by the TNRCC are consistently greater in central Texas than other regions of the State (Hornig and others, 1995). Invertebrate samples collected from the streams in this area have included more than 50 taxa from 3 square feet $\left(\mathrm{ft}^{2}\right)$ of stream bottom (Bayer and others, 1992).

The habitat and accompanying biota of the streams in the study-unit basins change substantially in the downstream reaches. The SCTX study unit extends into the Southern Texas Plains (to the southwest), the East Central Texas Plains and Western Gulf Coastal Plain (to the southeast), and the Texas Blackland Prairies (to the east). The streams in these ecoregions are characterized by warm, turbid water; dominated by soft-bottom runs and pools (with only occasional riffles); and bordered by highly erodible streambanks (Bayer and others, 1992). Warm-water, stress-tolerant species predominate in the streams of these ecoregions.

\section{Guadalupe River Basin}

The Guadalupe River originates in Kerr County at about 1,800 feet (ft) above mean sea level and joins the San Antonio River 11 miles (mi) upstream from Guadalupe Bay (part of San Antonio Bay) (fig. 1). The river is about $410 \mathrm{mi}$ long with a drainage area of about $6,000 \mathrm{mi}^{2}$. The 30-year (1961-91) normal precipitation in the basin ranges from about 30 inches (in.) near the headwaters to about $40 \mathrm{in}$. near the coast (Dallas Morning News, Inc., 1997, p. 113-118). Annual mean discharge of the Guadalupe River into Guadalupe Bay is 1,867 cubic feet per second $\left(\mathrm{ft}^{3} / \mathrm{s}\right.$ ) (on the basis of 1935-97 water-year records at USGS streamflowgaging station 08176500 Guadalupe River at Victoria (Gandara and others, 1998)). Canyon Dam, forming Canyon Lake (fig. 1), was completed in 1964 for flood control, water storage, hydroelectric power generation, and recreational uses. With the closing of the dam, the Guadalupe River became a regulated river over much of its length, rarely subject to the wide range of natural flows that are typical of this region. Daily mean discharge from Canyon Dam ranges from 0.80 to 5,680 $\mathrm{ft}^{3} / \mathrm{s}$, and annual mean discharge is $457 \mathrm{ft}^{3} / \mathrm{s}$ (on the basis of 1963-97 water-year records, the period of regulated streamflow, at USGS streamflow-gaging 
station 08167800 Guadalupe River at Sattler (Gandara and others, 1998)). The San Marcos River, with its confluence to the Guadalupe River in Gonzales County (fig. 1) provides the only regular input of substantial flow below Canyon Dam. The San Marcos is a springfed river; annual mean discharge from the springs is $170 \mathrm{ft}^{3} / \mathrm{s}$ (on the basis of 1957-94 water-year records at USGS streamflow-gaging station San Marcos River springflow at San Marcos (Gandara and others, 1995)). During periods of little or no precipitation, which result in low streamflows in other streams in the basin, the San Marcos River is the major contributor of streamflow in the Guadalupe River.

\section{San Antonio River Basin}

The San Antonio River (fig. 1) originates in metropolitan San Antonio (1996 estimated population 1.1 million (Dallas Morning News, Inc., 1997)) at about $690 \mathrm{ft}$ above mean sea level. The river flows southeasterly for about $240 \mathrm{mi}$ from the headwaters to its confluence with the Guadalupe River north of Guadalupe Bay, and has a drainage area of about 4,300 $\mathrm{mi}^{2}$. The 30 -year normal precipitation in the basin is similar to that in the Guadalupe River Basin. The annual mean discharge of the San Antonio River to the Guadalupe River near Guadalupe Bay is about $723 \mathrm{ft}^{3} / \mathrm{s}$ (on the basis of 1924 97 water-year records at USGS streamflow-gaging station 08188500 San Antonio River at Goliad (Gandara and other, 1998)). Stream quality of the San Antonio River is affected a short distance downstream of the headwaters by numerous municipal and industrial wastewater discharges and by urban runoff. During low-flow conditions, flow is predominantly treated wastewater. The Medina River (fig. 1) is a major tributary of the San Antonio River. Annual mean discharge of the Medina River is $206 \mathrm{ft}^{3} / \mathrm{s}$ (on the basis of 193997 water-year records at USGS streamflow-gaging station 08181500 Medina River at San Antonio (Gandara and others, 1998)). Salado, Leon, and Cibolo Creeks (fig. 1) are minor tributaries that contribute little to the base flow of the San Antonio River. Cibolo Creek begins as a spring-fed creek in the Edwards Plateau, contributing recharge to the Edwards aquifer as it flows across the aquifer recharge zone.

\section{Nueces River Basin}

The Nueces River Basin (fig. 1) is the largest of the three major basins in the study unit. The Nueces River originates in Edwards County at about 1,600 ft above mean sea level and flows about $440 \mathrm{mi}$ from the headwaters to its mouth at Nueces Bay. The 30-year normal precipitation (1961-90) in the basin ranges from $21 \mathrm{in.}$ in the upper basin to 35 in. near the coast (Dallas Morning News, Inc., 1997, p. 113-118). Although the Nueces River has a large drainage area (about 17,000 $\mathrm{mi}^{2}$ ), it has the smallest annual mean discharge of the three major rivers in the study unit $-135 \mathrm{ft}^{3} / \mathrm{s}$ (on the basis of 1939-97 water-year records at USGS streamflow-gaging station 80192000 Nueces River below Uvalde (Gandara and others, 1998)). The Nueces River and its upstream tributaries, including the Frio and Sabinal Rivers and Seco and Hondo Creeks, originate from seeps and springs in the Edwards Plateau. As the streams cross the Balcones fault zone to the south (fig. 1), a substantial amount of flow from these streams enters the Edwards aquifer. The Nueces River is the only stream in the basin that regularly maintains some flow beyond the recharge zone. Mostly erratic rainfall provides much of the streamflow for the Nueces River and its tributaries south of the Balcones fault zone, with periods of no flow in the lower reaches of the Nueces River.

\section{Minor Coastal Basins}

Two minor basins in the SCTX study unit drain coastal areas directly into the Gulf of Mexico. Streamflows in these basins are primarily dependent on precipitation. The San Antonio-Nueces Coastal Basin has a drainage area of about 2,600 $\mathrm{mi}^{2}$, and the Nueces-Rio Grande Coastal Basin has a drainage area of about 280 $\mathrm{mi}^{2}$. The 30-year (1961-90) normal precipitation in the coastal basins ranges from about 30 to 40 in. (Dallas Morning News, Inc., 1997, p. 113-118).

\section{Edwards Plateau Ecoregion}

The Edwards Plateau ecoregion, encompassing about $6,500 \mathrm{mi}^{2}$ ( 25 percent of the study unit), also is known locally as the Edwards Plateau or Texas Hill Country. The topography is hilly with elevations from $800 \mathrm{ft}$ to more than $1,800 \mathrm{ft}$ above mean sea level and is commonly incised by streams. The Edwards Plateau receives 16 to 33 in. of precipitation annually, increasing from west to east (Gould, 1975). Soils are mostly shallow, underlain by limestone or caliche. Typical land use is grazed open woodland, grazed forest, and woodland; some subhumid grassland; and semiarid grazing (Anderson, 1970). 


\section{Texas Blackland Prairies Ecoregion}

The Texas Blackland Prairies ecoregion encompasses about $2,700 \mathrm{mi}^{2}$ (8.7 percent of the study unit). The topography of the region is gently rolling to relatively flat, with elevations from 300 to $800 \mathrm{ft}$ above mean sea level. The region is well dissected by streams, which allow for rapid drainage. Soils associated with this region are fairly uniform, dark-colored calcareous clays interspersed with some gray, acid sandy loams. Annual precipitation varies from $30 \mathrm{in}$. for the western part to more than $40 \mathrm{in}$. for the eastern part (Gould, 1975). Land use is primarily cultivated cropland (Anderson, 1970).

\section{East Central Texas Plains Ecoregion}

The East Central Texas Plains ecoregion encompasses about $5,500 \mathrm{mi}^{2}$ (18 percent of the study unit). The region consists of rolling to hilly landscapes with elevations from about 300 to $800 \mathrm{ft}$ above mean sea level. Annual precipitation varies from 35 to 45 in. (Gould, 1975). Soils range from acid sandy loams or sands to clays. Land use is typically woodland with some cropland and pasture (Anderson, 1970).

\section{Western Gulf Coastal Plain Ecoregion}

The Western Gulf Coastal Plain ecoregion encompasses about $3,400 \mathrm{mi}^{2}$ (11 percent of the study unit). This poorly drained plain is less than $150 \mathrm{ft}$ above mean sea level and is dissected by streams flowing into the Gulf of Mexico. Annual precipitation varies from about $20 \mathrm{in}$. for western areas to about $50 \mathrm{in}$. for eastern areas (Gould, 1975). Soils are acid sands, sandy loams, and clays. Cropland and cropland with grazing are the dominant land uses (Anderson, 1970).

\section{Southern Texas Plains Ecoregion}

Encompassing about $12,000 \mathrm{mi}^{2}$ (35 percent of the study unit), the Southern Texas Plains is the largest ecoregion in the study unit. The topography is level to rolling hills with elevations from about 0 to $1,000 \mathrm{ft}$ above mean sea level. Annual precipitation varies from $16 \mathrm{in}$. for the western part to $35 \mathrm{in}$. for the eastern part (Gould, 1975). Soils range from clays to clay loams. Predominant land use is grazed open woodland, subhumid grassland, and semiarid grazing land (Anderson, 1970).

\section{Edwards Aquifer Habitats}

The western part of the Edwards aquifer, known as the San Antonio region, extends from Hays County to Kinney County within the SCTX study unit. The deposition of the material that became the carbonate rocks of the Edwards aquifer began almost 100 million years ago in a shallow sea. Repeated submergence and exposure of the carbonate rocks allowed early formation of cavernous porosity. Hundreds of feet of sediments were deposited over this early aquifer, and as the North American continent was slowly uplifted, the Cretaceous seas began to recede, allowing streams to cut into the sediments and expose the underlying Edwards aquifer. A period of extensive faulting during the Miocene (12 to 17 million years ago) resulted in the formation of the Balcones fault zone. With the changes imposed by the new faults, new ground-water movement was manifested in some areas as recharge points and in other areas as resurgence points or springs (Longley, 1986).

The high permeability of the Edwards aquifer results from the freshwater diagenesis of faulted and fractured carbonate rocks. After the rocks were broken and displaced during the Balcones faulting, large quantities of freshwater infiltrated strata that previously had been isolated from the surface (Kastning, 1983). Subsequent faulting processes were initiated that eventually provided an extremely transmissive (fastmoving) ground-water-flow system (Abbott, 1975). The present-day aquifer is riddled with joint cavities and solution channels (caverns) that have evolved through erosional unloading and dissolution. The outcrop area has a porous, honeycombed, or Swiss cheese appearance because of the preferential leaching of soluble materials (Barker and Ardis, 1996).

Many wells penetrate caverns in the area around San Antonio (Livingston, 1947; Petitt and George, 1956). It is estimated that in 1975, wells and springs in Bexar County discharged 259.0 thousand acre-feet (acre-ft) of water from the Edwards aquifer, with about 15 percent of this discharge from springs (Rappmund, 1976, p. 5). In reviewing publications on the hydrology of the Bexar County area, Petitt and George (1956) noted that the well logs of a large percentage of the wells in the San Antonio area included some cavernous areas. These areas could provide sufficient space for propagation of aquatic organisms. 
The USGS and various Texas water agencies have conducted analyses on the chemical quality of the Edwards aquifer in the San Antonio region (Garza, 1962; Pearson and Rettman, 1976; Reeves, 1976; Reeves and others, 1972). In general these publications provide information on the geochemistry of the area.

Other publications give insight into how the water movement occurs within the Edwards aquifer in the San Antonio region (Abbott, 1977; Maclay and Small, 1976; Pearson and Rettman, 1976; Pearson and others, 1975; Puente, 1976). In general, the movement in the aquifer is from the west to the east or northeast. Numerous publications discuss the hydrology of the aquifer specifically and include water levels, recharge, discharge, amounts of precipitation, and other hydrologic properties (Follett, 1956; Garza, 1966; Lang, 1954; Maclay and Rettman, 1973; Puente, 1974; Rappmund, 1975, 1977; Rettman, 1969; Sieh, 1975). Hydrologic models have been developed for predictive purposes on the basis of increased population and subsequent increased water use. These models indicate that without additional recharge, the average water level in the aquifer will continue to drop in the future (Wanakule, 1988). Other than a reduction in springflow, it is not clear how water-level declines would affect the availability of habitats for spring and aquifer organisms in the region.

\section{STREAM BIOLOGY}

The three most dominant biological groups that typically form stream communities are fish, aquatic invertebrates (chiefly arthropods, molluscs, and segmented worms), and attached algae (the primary producers). The fish and invertebrates include species specialized as primary consumers (of the algae), as detritivores (shredders of terrestrial debris entering the stream or filterers and gatherers of fine organic particles), and as predators. Other species are omnivorousopportunistic consumers of several food sources. Aquatic species also have specific habitat requirements; a stream community will be determined largely by the available habitat (stony riffle, sandy run, or softbottom pool). The condition of the habitat (including embeddedness of stones, amount of cover from instream structures and streambank features, and contaminants in bottom sediments and food) and the quality of the water (temperature, light, $\mathrm{pH}$, conductivity, dissolved oxygen, nutrients, and dissolved and suspended solids) can affect the distribution of aquatic organisms. Other factors that affect the distribution of organisms include dispersal (proximity of colonization areas or downstream barriers such as dams), predation and competition from native and introduced species, food sources from upstream and terrestrial inputs, and hydrologic conditions such as floods and droughts.

The resident stream biota reflect both the current and recent conditions of the habitat, water-quality, and hydrologic factors. In general, algae integrate the previous days to weeks of conditions, and invertebrates can reflect conditions during their lifespans of several months to a year; and fish can reflect previous conditions for as much as several years. The biological groups also differ in the specificity of the environment they reflect: The less-mobile algae and invertebrates reflect recent conditions within a specific pool, run, or riffle, and the more-mobile fish can integrate conditions over much greater distances.

\section{Vertebrate Communities}

Thirty-two studies of vertebrates (primarily fish) in streams in the SCTX study unit published mostly during the 1980s and 1990s are summarized in table 1 (at end of report). The locations of many of the studies (those with specifically identifiable sampling sites) are shown in figures 2 and 3 . The majority of the reports list taxa and numbers of fish for the study sites. When coupled with the report by Young and others (1973), an extensive amount of fish data are available for the study unit. About 140 fish species from the SCTX study unit are listed by the Texas System of Natural Laboratories, Inc. (1994) (table 2, at end of report).

Hubbs (1957) suggested that the distribution of fish closely follows climatological and geologic factors because these factors affect the chemical and physical properties of aquatic systems. The SCTX study unit is a highly diverse assemblage of environments controlled by the wide variety of climatic, topographic, soil, and biotic factors in the region (Blair, 1950; Gould, 1975). In the analysis of fish collections from eastern and central Texas in 1953 and in 1986, Anderson and others (1995) showed the relative region-wide stability in species diversity during 33 years. Despite this encouraging trend, the report indicated that, for localized areas, several species had become extinct or endangered. 


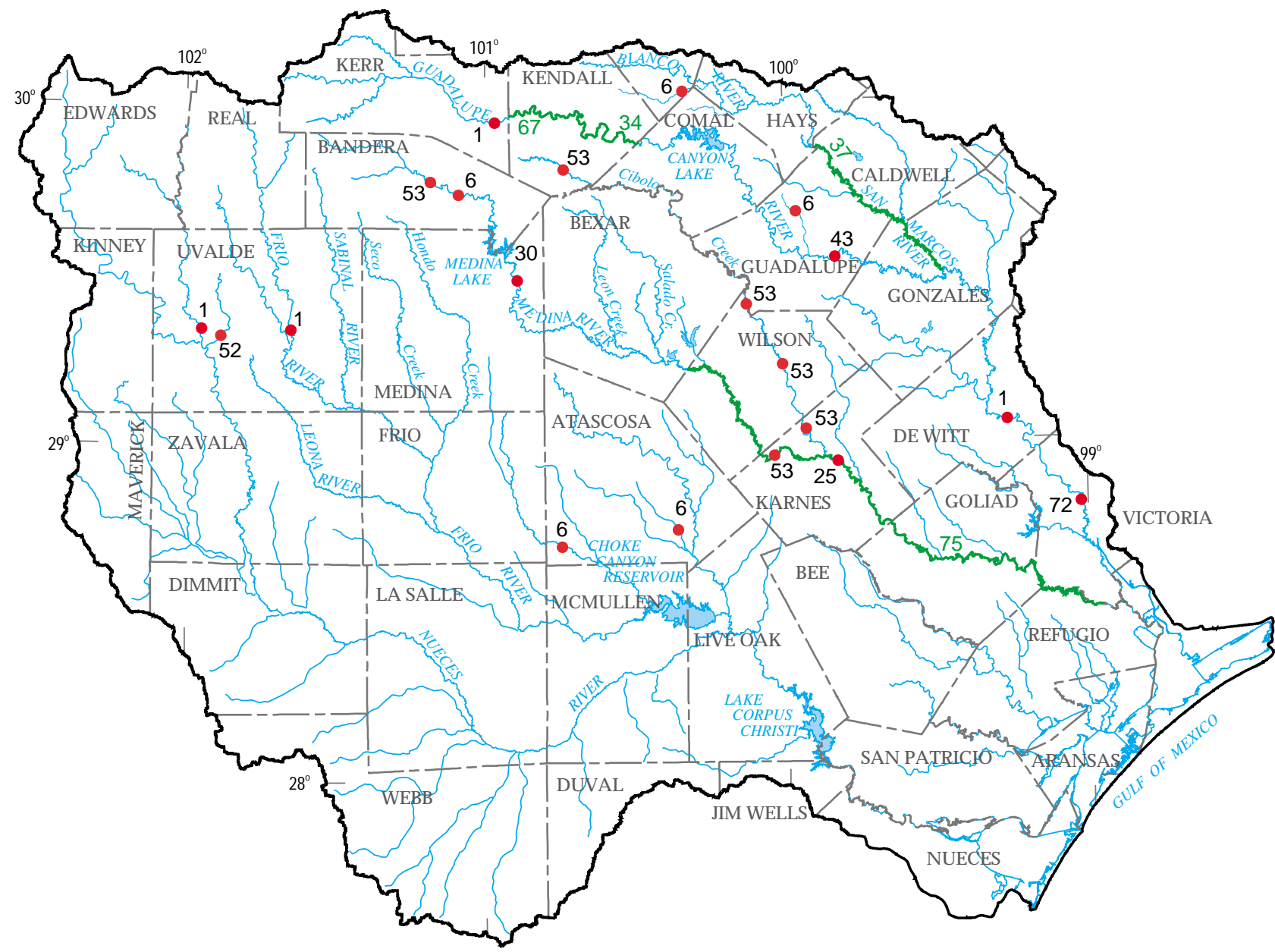

$\stackrel{2}{0 \quad 20 \quad 40 \quad 60 \text { M ILES }}$

\section{EXPLANATION}

River reach sampling area

52

Sampling site

Number referenced in table 1

Figure 2. Locations of previous fish studies in the South-Central Texas study unit, Texas.

\section{Invertebrate Communities}

Fifty-four studies of aquatic invertebrates published during 1971-97 are summarized in table 1. The locations of most of the studies (those with specifically identifiable sampling sites) are shown in figures 4 and 5. Surveys, species composition reports, and theses make up the majority of studies concerning invertebrates in the study area. Most of the reports list taxa and numbers of invertebrates collected at the study sites. Although aquatic vertebrates in Texas have been well documented (Hubbs and others, 1991), complete species inventories for most groups of aquatic invertebrates 


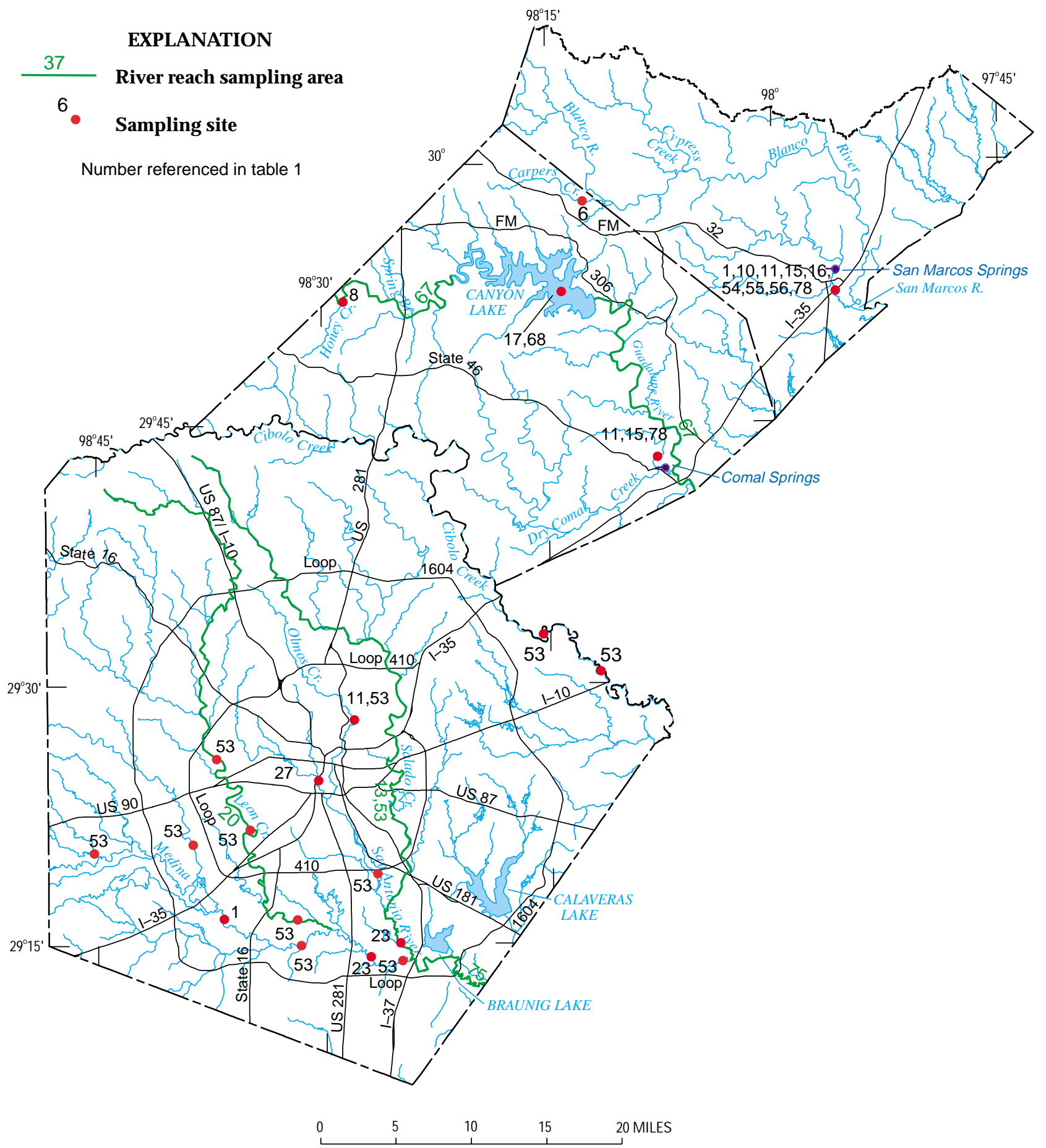

Figure 3. Locations of previous fish studies in Bexar, Comal, and Hays Counties, Texas.

are lacking (Bowles and Arsuffi, 1993). One of the more complete recent studies catalogued invertebrates from the least-impacted streams of the Texas ecoregions (Bayer and others, 1992). About 180 aquatic invertebrate species were collected from the SCTX study unit (table 3, at end of report).

\section{Plant Communities}

Thirteen studies of plant communities published during 1940-97 are summarized in table 1 . The majority of the reports are listings of taxa or distributions within the study unit. There also are secondary 


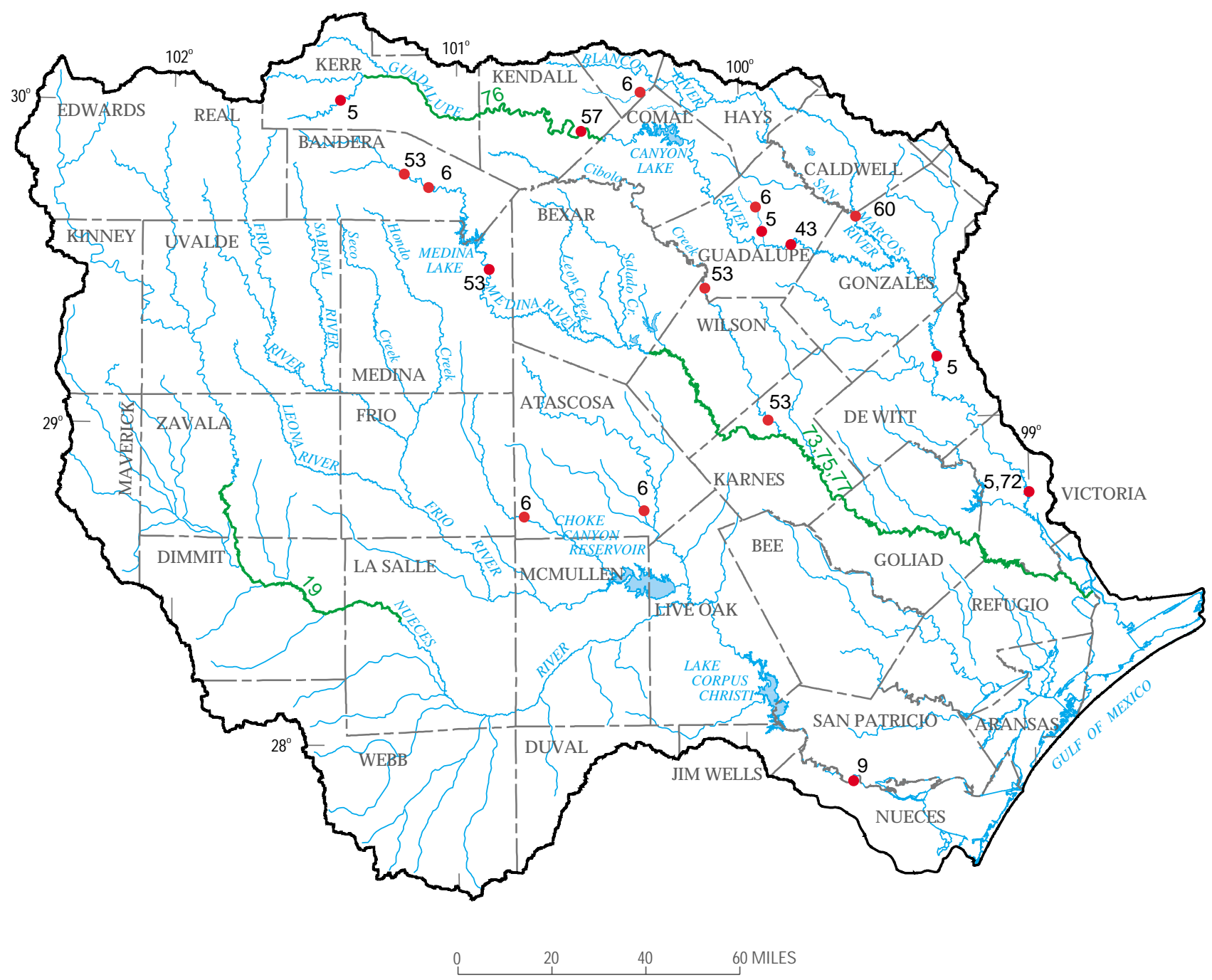

\section{EXPLANATION}

19

River reach sampling area

6 Sampling site

Number referenced in table 1

Figure 4. Locations of previous aquatic invertebrate studies in the South-Central Texas study unit, Texas.

references to plant communities and their role as habitat for, or impact on, endangered species (Bowles and Arsuffi, 1993; Power, 1996). Macrophytes are the focus of all the plant studies listed in table 1 partly because of the importance of macrophytes in Comal and San Marcos Springs, the two largest springs in Texas.
About 30 aquatic plants have been identified in the study unit (table 4, at end of report).

\section{Species of Concern}

Threats to the continued existence of aquatic endemics (native species unique to the area) typically 


\section{EXPLANATION}

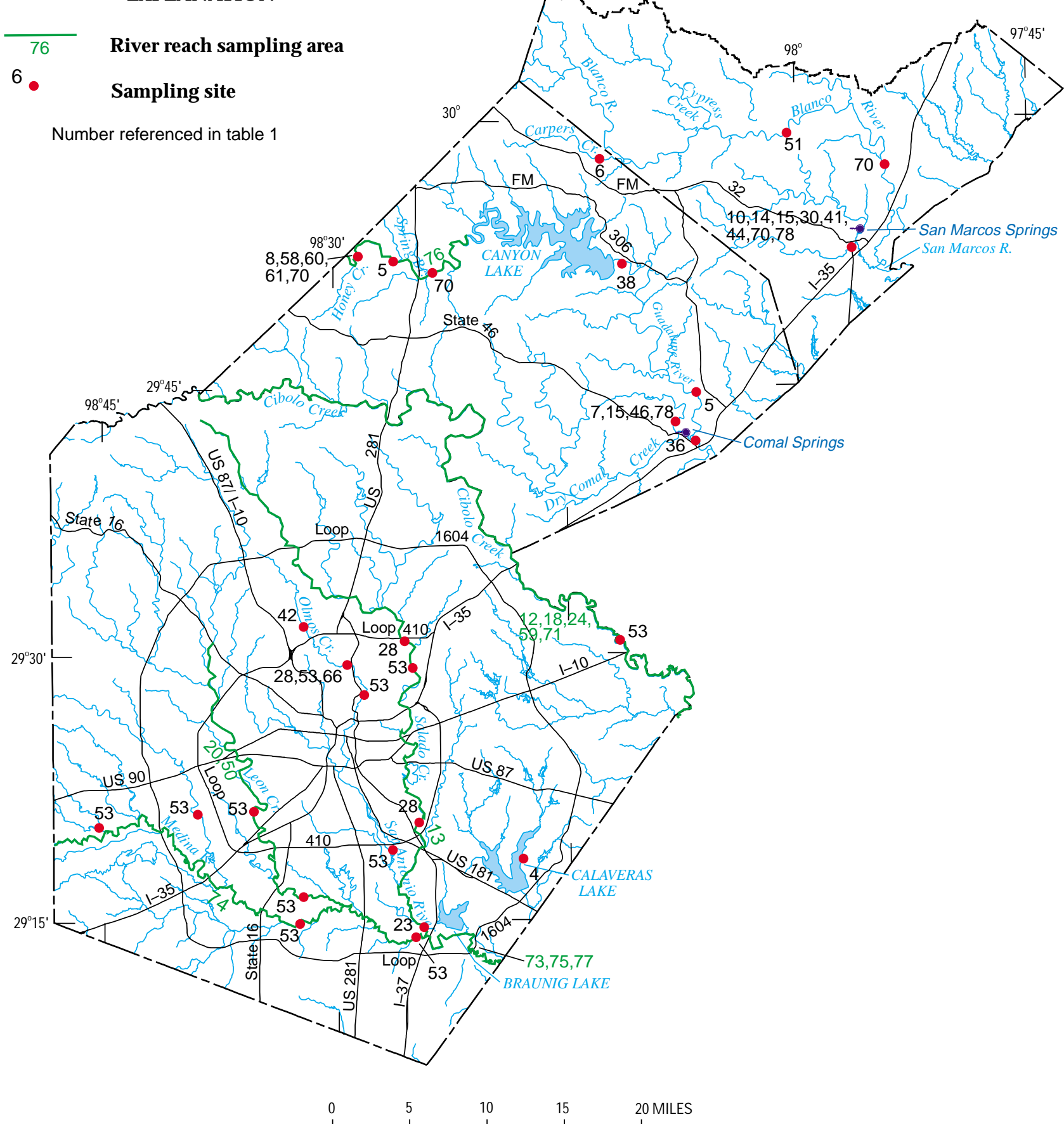

Figure 5. Locations of previous aquatic invertebrate studies in Bexar, Comal, and Hays Counties, Texas.

are anthropogenic and include "agricultural practices, impoundments and flood-control projects, siltation from erosion, ground-water pumping, introduction of non-native species, recreational activities, wastewater discharge, and general pollution" (Bowles and Arsuffi, 1993, p. 320). Allan and Flecker (1993, p. 35) listed six factors as critical in flowing water systems: "habitat loss and degradation, the spread of nonnative species, overexploitation, secondary extinctions (loss of a species resulting from loss of one or more other species), chemical and organic pollution, and climate change." With respect to non-native species, 
they suggest that more tolerant invaders might gain a foothold because of favorable conditions, reduction of the native fauna population, or alteration and degradation of habitat.

\section{Introduced Species}

Non-native species, that is, those species introduced into an area outside their natural range (or in the case of "exotic" species, from outside the continent) present a threat to Federally listed (endangered or threatened) species and their habitat (U.S. Fish and Wildlife Service, 1995). Competition, predation, hybridization, and habitat modification by non-natives have been identified as major factors threatening endemic organisms (Bowles and Arsuffi, 1993; Ono and others, 1983; U.S. Fish and Wildlife Service, 1995). The SCTX study unit has more than 30 known nonnative aquatic species (table 5, at end of report), many of tropical origin. Their ability to survive cold winters often relates directly to the minimum annual water temperature. For example, exotic giant ramshorn snails (Marisa cornuarietis) have been shown to withdraw into their shells and collect on the bottom substrates at 19 degrees Celsius $\left({ }^{\circ} \mathrm{C}\right)$. These organisms die within 5 hours upon exposure to a temperature of $8^{\circ} \mathrm{C}$ (Robins, 1971), thereby effectively limiting their range. Most spring-fed streams in the study unit have temperature ranges within $1{ }^{\circ} \mathrm{C}$ and thus provide suitable habitat for these snails and many other tropical species that would otherwise die from minimum winter temperatures (Hubbs, 1995). The introduction and subsequent survival of the blue tilapia (Tilapia aurea) into heated power-plant effluent reservoirs and into the spring-fed upper reaches of the San Marcos, Comal, and San Antonio Rivers (Hubbs and others, 1991) is an excellent example of this phenomenon.

\section{Endangered and Threatened Species}

Hubbs and others (1991) estimated that 20 percent of the 169 native Texas freshwater species are in potential danger of extirpation (range reduction) or extinction. Of the 19 aquatic species listed in Texas by the USFWS as endangered or threatened, 8 are associated with the SCTX study unit. Table 6 (at end of report) lists the species considered to be of concern (proposed for listing, endangered, or threatened) in Texas by the USFWS, TPWD, or by the Texas Organization for Endangered Species (TOES). Endangered and threatened species are at the center of a complex battle over water rights within the study unit. The San Marcos and Comal Springs and Associated Aquatic Ecosystems Recovery Plan (revised) was developed to ensure the survival of listed species in their native systems through an ecosystem approach to the recovery of multiple species (U.S. Fish and Wildlife Service, 1995). The San Marcos gambusia (Gambusia georgei) is presumed extinct (Miller and others, 1989), and its case is indicative of the problems of many of the endemics throughout the study unit. Its habitat was restricted to the upper San Marcos River (spring run) where, even historically, the organism was rare and difficult to find. Ono and others (1983) list habitat alteration, pollution, and competition with the introduced Gambusia affinis as the probable causes for the extinction of G. georgei. This species has not been collected in the wild since 1982 (Hubbs and others, 1991).

All of the Federally listed endangered species in the study unit are associated with springs and spring runs, thereby emphasizing the importance of conservation of these habitats. Hubbs (1995) noted that spring fish seldom are found at any substantial distance from the springs and that the area occupied by the endemics is related directly to the volume of water flowing from the springs. Hubbs also reported that droughts reduce available habitats.

\section{AQUIFER BIOLOGY}

Strayer (1994) noted that the Edwards aquifer in the SCTX study unit is one of a few regions in the world where a large diversity of subterranean species are found. Longley (1981) reported that the Edwards aquifer might be the most diverse subterranean biological community on earth. The list of species associated with the aquifer is large and is expected to grow as more faunal studies are completed. Both vertebrate (salamanders and two species of blind catfish) and invertebrate troglobitic (restricted to ground-water habitats) species have been found within this aquifer. Ninety-one species or subspecies, including 44 troglobitic species, have been identified as endemic to the aquatic ecosystems (including springs) associated with the Edwards aquifer (Barr and Spangler, 1992; Bowles and Arsuffi, 1993; Longley, 1986). Table 7 (at end of report) lists the known endemic troglobitic species of the Edwards aquifer.

Longley (1986) reported that the biological invasion of the Edwards aquifer probably began during the deposition of the Edwards Limestone more than 
100 million years ago. Alternate periods of submergence and exposure of the region by the shallow Cretaceous sea allowed early formation of caverns. At least 10 crustaceans found in the Edwards aquifer are related to typically marine species and likely evolved from the marine environment that last covered the area during the late Cretaceous or early Tertiary (65 to 70 million years ago) (Holsinger and Longley, 1980).

About 12 to 17 million years ago, during the Miocene, a period of extensive faulting in south-central Texas began that resulted in the subsequent formation of the Balcones fault zone, changing the movement patterns of ground water within the Edwards (Longley, 1986). This faulting created new springs and points of surface-water entry (recharge) into the ground water (Barker and Ardis, 1996), providing many new entry locations for the freshwater species of south-central Texas. During this time, further dissolution of the limestone increased cavernous porosity in the limestone; this increased formation of caverns in the limestone, and the linkage between caverns created new habitat and distribution patterns for the area ground-water species.

Langecker and Longley (1993) believe extensive cave development during the Miocene could have allowed colonization of the ancestors of the two species of blind catfish presently in the Edwards aquifer. Langecker and Longley (1993) conclude that the morphological adaptations of these fish, including degree of eye reduction, are evidence that these fish are among the oldest known cave fish.

Invasions of an aquifer by freshwater organisms are most likely during periods of environmental stress (Holsinger, 1988). Longley (1986) indicated that the onset of the ice age 3 million years ago had a major influence on the biology of the Edwards aquifer. During extremely cold periods, the ground water maintains constant temperature and offers a refuge for aquatic organisms. Severe droughts in the region also could have contributed to the invasion of the Edwards; in particular, the ground-water salamanders of Central Texas could have migrated into cave streams when their surface habitats dried up (Sweet, 1982).

Because of the lack of light within the aquifer, food derived from photosynthesis is not available to the ground-water communities. In the area near San Marcos Springs, where the aquifer habitat is near the recharge zone, organic debris washed in from the surface is the source of energy to the primary consumers, chiefly amphipods, shrimp, and snails (Browning, 1977; Longley, 1981). Here the blind salamanders are at the top of the food chain; captive specimens have been observed feeding on a variety of aquifer invertebrates (Longley, 1981). Another likely predator is a blind species of the predaceous diving beetle family.

In deeper parts of the aquifer (1,300 to 2,000 ft) near San Antonio, the organic matter brought in from distant recharge areas would not be sufficient to support the aquifer biota. Instead, it has been theorized that fossil organic matter supports fungi and bacteria, which in turn support the invertebrates and blind catfish in this region of the Edwards aquifer (Longley, 1981). The food source might also be similar to that discovered at Movile Cave in Romania, which is isolated from terrestrial inputs. The energy source for the diverse community of organisms in Movile Cave appears to be hydrogen sulfide-fixing bacteria (Sarbu and others, 1996). The top of the food chain in the deeper parts of the Edwards aquifer appears to be occupied by the widemouth blindcat, Satan eurystomus, whose stomach contents include crustacean skeletons (Langecker and Longley, 1993). The mouthparts and stomach contents of the other catfish in the aquifer, the toothless blindcat (Trogloglanis pattersoni), indicate that it forages on organic matter coating the cave walls.

\section{SUMMARY}

The USGS NAWQA Program is an interdisciplinary program designed to assess water quality across the Nation using chemical, physical, and biological measures. The program is based on investigations of more than 50 study units encompassing one or more major river basins and aquifers. Intensive field investigations and retrospective reports of existing environmental data in the study units increase the understanding of the status of and trends in the resource quality of these aquatic systems. This retrospective report summarizes available information on aquatic biology of the streams and rivers in the Guadalupe, San Antonio, and Nueces River Basins, and the San Antonio-Nueces and Nueces-Rio Grande Coastal Basins, and of the Edwards aquifer where it underlies the three river basins. The biology of the study-unit streams is determined mostly by the characteristics of the ecoregions they transect. The ecoregions are the Edwards Plateau, Texas Blackland Prairies, East Central Texas Plains, Western Gulf Coastal Plain, and Southern Texas Plains.

This report summarizes in table format 32 aquatic vertebrate (primarily fish), 54 aquatic invertebrate, and 
13 aquatic plant studies, published mostly during 197397. About 20 percent of the previous fish and invertebrate studies and about 75 percent of the aquatic plant studies have centered on Comal Springs in Comal County and San Marcos Springs in Hays County, the two largest springs in Texas. Although several important studies are available for the San Antonio region, documentation of aquatic biology of the remainder of the study unit is relatively sparse.

The SCTX study unit is unique in that it contains a diversity of both surface-water and aquifer habitats. The streams, particularly in the Edwards Plateau, support three dominant biological groups-fish, aquatic invertebrates, and plants. Potential threats to the endemic (native) species exist, such as impoundments and flood-control projects, siltation from erosion, ground-water pumping, recreational activities, wastewater discharge, and introduction of non-native species. More than 30 non-native fish, invertebrate, and plant species have been introduced into the region, including the giant ramshorn snail and blue tilapia of tropical origin that are able to survive the relatively mild and constant temperatures of springs in the study area. About 20 percent of native Texas freshwater species are in potential danger of extirpation (range reduction) or extinction. Of the 19 aquatic species Federally listed as endangered or threatened in Texas, 8 are associated with springs and spring runs in the SCTX study unit. All of the endangered species in the study unit are associated with springs and spring runs.

A large number of endemic species in the study unit are associated with subterranean aquatic ecosystems, most likely a consequence of the unique proximity of the varied topographic and hydrologic conditions of the area and of the geological development of the Edwards aquifer. Ninety-one endemics, including 44 species found solely underground, are associated with the aquatic ecosystems (including springs) of the Edwards aquifer.

\section{SELECTED REFERENCES}

Abbott, P.L., 1975, On the hydrology of the Edwards Limestone, south-central Texas: Journal of Hydrology, v. 24 , p. 251-269.

1977 , Effect of Balcones faults on groundwater movement, south-central Texas: Texas Journal of Science, v. 29 , no. $1-2$, p. 514 .

Allan, J.D., and Flecker, A.S., 1993, Biodiversity conservation in running waters: BioScience, v. 43 , no. 1 , p. 32-43.
Anderson, A.A., Hubbs, C., Winemiller, K.O., and Edwards, R.J., 1995, Texas freshwater fish assemblages following three decades of environmental change: The Southwestern Naturalist, v. 40, no. 3, p. 314-321.

Anderson, J.R., 1970, Major land uses, in The national atlas of the United States: Washington, D.C., U.S. Geological Survey, pls. 158-159.

Angerstein, M.B., and Lemke, D.E., 1994, First records of the aquatic weed Hygrophila polysperma (Acanthaceae) from Texas: Sida, v. 16, no. 2, p. 365-371.

Ashworth, J.B., and Hopkins, Janie, 1995, Aquifers of Texas: Texas Water Development Board Report 345, 69 p.

Barker, R.A., and Ardis, A.F., 1996, Hydrogeologic framework of the Edwards-Trinity aquifer system, westcentral Texas: U.S. Geological Survey Professional Paper 1421-B, $61 \mathrm{p}$.

Barr, C.B., and Spangler, P.J., 1992, A new genus and species of stygobiontic dryopid beetle, Stygoparnus comalensis (Coleoptera: Dryopidae), from Comal Springs, Texas: Proceedings of the Biological Society of Washington, v. 105 , no. 1 , p. 40-54.

Barr, T.C., Jr., and Holsinger, J.R., 1985, Speciation in cave faunas: Annual Review of Ecological Systematics, v. 16, p. 313-337.

Barra, T.C., 1976, The effects of a heated effluent on the species diversity of benthic macroinvertebrates in Calaveras Lake, a central Texas reservoir: San Marcos, Tex., Southwest Texas State University, M.S. thesis, $70 \mathrm{p}$.

Bayer, C.W., 1975, The dragonfly nymphs (Odonata: Anisoptera) of the Guadalupe River Basin, Texas: San Marcos, Tex., Southwest Texas State University, M.S. thesis, $117 \mathrm{p}$.

Bayer, C.W., Davis, J.R., Twidwell, S.R., Kleinsasser, Roy, Linam, Gordon, Mayes, Kevin, and Hornig, Evan, 1992, Texas Aquatic Ecoregion Project-An assessment of least disturbed streams: Austin, Tex., Draft report for Texas Water Commission, $406 \mathrm{p}$.

Blair, W.F., 1950, The biotic provinces of Texas: Texas Journal of Science, v. 2, no. 1, p. 93-117.

Bosse, L.S., Tuff, D.W., and Brown, H.P., 1988, A new species of Heterelmis from Texas (Coleoptera: Elmidae): The Southwestern Naturalist, v. 33, no. 2, p. 199-203.

Bowles, D.E., 1994, A preliminary checklist of the caddisflies (Insecta: Trichoptera) of Comal Springs, Texas: Austin, Tex., Texas Parks and Wildlife Department, Resource Protection Division, Endangered Resources Branch, 9 p.

1995, A new species of Austrotinodes (Trichoptera: Ecnomidae) from Texas: Journal of the New York Entomological Society, v. 103, no. 2, p. 155-161.

Bowles, D.E., and Arsuffi, T.L., 1993, Karst aquatic ecosystems of the Edwards Plateau region of central 
Texas, USA-A consideration of their importance, threats to their existence, and efforts for their conservation: Aquatic Conservation, Marine and Freshwater Ecosystems, v. 3, p. 317-329.

Bowles, D.E., and Flint, O.S., Jr., 1997, The genus Phylloicus Muller (Trichoptera: Calamoceratidae) in the United States, with a redescription of Phylloicus ornatus (Banks): Proceedings of the International Symposium on Trichoptera, 1997, p. 53-58.

Bowles, D.E., and Short, R.A., 1988, Size composition of invertebrate drift and fish predation in a Texas stream: The Southwestern Naturalist, v. 33, no. 2, p. 177-184.

Bowles, D.E., and Stanford, R., 1997, A new distributional record for Haideoporus texanus (Coleoptera: Dytiscidae), a stygobiontic beetle from the Edwards aquifer, Texas: Entomological News, v. 108, no. 4, p. 297-299.

Bowman, James, and Jensen, D.A., 1977, Intensive surface water monitoring survey for segment no. 2101-Nueces River tidal: Austin, Tex., Texas Water Quality Board, Field Operations Division, Report IMS-53, 29 p.

Bowman, T.E., and Longley, Glenn, 1976, Redescription and assignment to the new genus Lirceolus of the Texas troglobitic water slater, Asellus smithii (Ulrich) (Crustacea: Isopoda: Asellidae): Proceedings of the Biological Society of Washington, v. 88, no. 45, p. 489-496.

Boyd, C.E., 1970, Vascular aquatic plants for mineral nutrient removal from polluted waters: Economic Botany, v. 24, no. 1, p. 95-103.

Bradsby, D.D., 1994, A recreational use survey of the San Marcos River: San Marcos, Tex., Southwest Texas State University, M.S. thesis, $82 \mathrm{p}$.

Brown, W.H., 1953, Introduced fish species of the Guadalupe River Basin: Texas Journal of Science, v. 5, no. 2, p. 245-251.

Browning, L.A., 1977, Source of nitrate in water of the Edwards aquifer, south-central Texas: Austin, Tex., University of Texas, M.S. thesis, 89 p.

Brune, Gunnar, 1981, Springs of Texas: Fort Worth, Tex., Branch-Smith, Inc., v. 1, 566 p.

Buzan, D., 1982a, Intensive survey of Cibolo Creek, segment 1902: Austin, Tex., Texas Department of Water Resources, Water Quality Assessment Unit, Report IS-39, $56 \mathrm{p}$.

1982b, Intensive survey of Salado Creek, segment 1910: Austin, Tex., Texas Department of Water Resources, Water Quality Assessment Unit, Report IS- $42,48 \mathrm{p}$.

Campbell, Linda, 1995, Endangered and threatened animals of Texas: Austin, Tex., University of Texas Press, $130 \mathrm{p}$.

Carpenter, S.R., and Lodge, D.M., 1986, Effects of submersed macrophytes on ecosystem processes: Aquatic Botany, v. 26, p. 341-370.
Coastal Ecosystems Management, Inc., 1975, Evaluation of impacts of a no-management plan on the San AntonioGuadalupe River Basin: Fort Worth, Tex., Coastal Ecosystems Management, Inc., $445 \mathrm{p}$.

Cover, L.W., 1980, The drift ecology of the Ephemeroptera (mayflies) in a spring-fed river: San Marcos, Tex., Southwest Texas State University, M.S. thesis, 94 p.

Crowe J.C., and Sharp, J.M., Jr., 1997, Hydrogeologic delineation of habitats for endangered species-The Comal Springs/River system: Berlin, Environmental Geology, v. 30, no. 1-2, p. 17-33.

Cuffney, T.F., Meador, M.R., Porter, S.D., and Gurtz, M.E., 1997, Distribution of fish, benthic invertebrate, and algal communities in relation to physical and chemical conditions, Yakima River Basin, Washington, 1990: U.S. Geological Survey Water-Resources Investigations Report 96-4280, 94 p.

Dallas Morning News, Inc., 1997, 1998-1999 Texas almanac: College Station, Tex., Texas A\&M Press, $672 \mathrm{p}$.

Davis, J.B., 1980, A comparison of growth of largemouth bass from selected areas of Canyon Reservoir, Texas: San Marcos, Tex., Southwest Texas State University, M.S. thesis, $47 \mathrm{p}$.

Davis, J.R., 1975, The ecology of the helminth parasites of Gambusia affinis and Gambusia geiseri (Osteichthyes: Poecillidae) in the area of San Marcos, Texas: Guadalupe-Blanco River Authority, Report 101, 161 p. 1982, Macrobenthic diversity of Cibolo Creek, an interrupted, south-central Texas stream, in Davis, J.R., ed., Proceedings of the Symposium on Recent Benthological Investigations in Texas and Adjacent States: Texas Academy of Sciences, Aquatic Sciences Section, p. 79-94.

Davis, W.S., Snyder, B.D., Stribling, J.B., and Stoughton, C., 1996, Summary of State biological assessment programs for streams and wadeable rivers: Washington, D.C., U.S. Environmental Protection Agency, Office of Policy, Planning and Evaluation, EPA 230-R-96-007.

De La Cruz, A.T., 1978, Intensive surface water monitoring survey for segment 2105-Nueces River: Austin, Tex., Texas Department of Water Resources, Report IMS-74, $34 \mathrm{p}$.

1994, Water quality and biological evaluationLeon Creek segment 1906: Austin, Tex., Texas Natural Resource Conservation Commission, Report AS-28, $62 \mathrm{p}$.

Devall, L.L., 1940, A comparative study of plant dominance in a spring-fed lake: San Marcos, Tex., Southwest Texas State University, M.A. thesis, 49 p.

Edwards, R.J., Longley, Glenn, Moss, Randy, Ward, John, Matthews, Ray, and Stewart, Bruce, 1989, A classification of Texas aquatic communities with special consideration toward the conservation of endangered 
and threatened taxa: Texas Journal of Science, v. 41, no. 3, p. 231-240.

Edwards, S.W., 1973, Texas caddisflies: Texas Journal of Science, v. 24, no. 4, p. 491-516.

Epperson, C.R., and Short, R.A., 1987, Annual production of Corydalus cornutus (Megaloptera) in the Guadalupe River, Texas: American Midland Naturalist, v. 118, no. 2, p. 433-438.

Espey, Huston and Associates, Inc., 1983, San Antonio River aquatic biological study: Austin, Tex., Document 83688, EH\&A Job 2827, 62 p.

Ezell, C.E., 1982, Intensive survey of Cibolo Creek, segment 1908: Austin, Tex., Texas Department of Water Resources, Water Quality Assessment Unit, Report IS-37, $42 \mathrm{p}$.

Findeisen, J.A., 1997, An assessment of fishes, biotic integrity, and fish habitat utilization in the lower San Antonio River: San Marcos, Tex., Southwest Texas State University, M.S. thesis.

Follett, C.R., 1956, Records of water-level measurements in Bexar County, Texas: Texas Board of Water Engineers Bulletin 5606, 60 p.

Fullington, R.W., 1982, The recent and fossil freshwater gastropod fauna of Texas, in Davis, J.R., ed., Proceedings of the Symposium on Recent Benthological Investigations in Texas and adjacent states: Texas Academy of Science, Aquatic Sciences Section, p. 61-67.

Gandara, S.C., Gibbons, W.J., Andrews, F.L., Fisher, J.C., Hinds, B.A., and Jones, R.E., 1995, Water resources data, Texas, water year 1994-v. 3: U.S. Geological Survey Water-Data Report TX-94-3, 475 p.

Gandara, S.C., Gibbons, W.J., Andrews, F.L., Jones, R.E., and Barbie, D.L., 1998, Water resources data, Texas, water year 1997—v. 3: U.S. Geological Survey WaterData Report TX-97-3, 414 p.

Garrett, G.P., 1991, Guidelines for the management of Guadalupe bass: Ingram, Tex., Texas Parks and Wildlife, Inland Fisheries Branch, 52 p.

Garza, Sergio, 1962, Recharge, discharge, and changes in ground-water storage in the Edwards and associated limestones, San Antonio area, Texas-A progress report on studies, 1955-59: Texas Board of Water Engineers Bulletin 6201, 42 p.

1966, Ground-water recharge to the Edwards and associated limestones, San Antonio area, Texas, 1964: San Antonio, Tex., Edwards Underground Water District Bulletin 9, 2 p.

Gilliom, R.J., Alley, W.M., and Gurtz, M.E., 1995, Design of the National Water-Quality Assessment ProgramOccurrence and distribution of water-quality conditions: U.S. Geological Survey Circular 1112, 33 p.

Ging, P.B., Judd, L.J., and Wynn, K.H., 1997, Water-quality assessment of south-central Texas-Occurrence and distribution of volatile organic compounds in surface water and ground water, 1983-94, and implications for future monitoring: U.S. Geological Survey WaterResources Investigations Report 97-4028, 20 p.

Gonzales, M., 1988, An examination of the biotic integrity of the upper San Antonio River based on fish community attributes: San Marcos, Tex., Southwest Texas State University, M.S. thesis.

Gould, F.W., 1975, Texas plants-A checklist and ecological summary: College Station, Tex., Texas A\&M University, Texas Agricultural Experiment Station, MP-585, $121 \mathrm{p}$.

Gregg, W.G., and Rose, F.L., 1982, The effects of aquatic macrophytes on the stream microenvironment: Aquatic Botany, v. 14, p. 309-324.

Hershler, Robert, and Longley, Glenn, 1986a, Hadoceras taylori, a new genus and species of phreatic Hydrobiidae (Gastropoda: Rissoacea) from south-central Texas: Proceedings of the Biological Society of Washington, v. 99, no. 1, p. 121-136.

1986b, Phreatic hydrobiids (Gastropoda: Prosobranchia) from the Edwards (Balcones fault zone) aquifer region, south-central Texas: Malacologia, v. 27, no. 1, p. 127-172.

1987, Phreatodrobia coronae, a new species of cavesnail from southwestern Texas: The Nautilus, v. 101 , no. 3 , p. 133-139.

Hobbs, H.H., Jr., and Hobbs, H.H., III, 1995, Procambarus (Ortmannicus) nueces (Decapoda: Cambaridae), a new crayfish from the Nueces River Basin, Texas: Proceedings of the Biological Society of Washington, v. 108 , no. 1, p. 54-60.

Holsinger, J.R., 1988, Troglobites-The evolution of cave-dwelling organisms: American Scientist, v. 76, p. 146-153.

Holsinger, J.R., and Longley, Glenn, 1980, The subterranean amphipod crustacean fauna of an artesian well in Texas: Smithsonian Contributions to Zoology, no. 308, 62 p.

Hornig, C.E., 1984, Macroinvertebrate inventories of the White River, Colorado and Utah-Significance of annual, seasonal, and spatial variation in the design of biomonitoring networks for pollution detection: Las Vegas, Nev., U.S. Environmental Protection Agency, EPA-600/S7-84-063, 4 p.

Hornig, C.E., Bayer, C.W., Twidwell, S.R., Davis, J.R., Kleinsasser, R.J., Linam, G.W., and Mayes, K.B., 1995, Development of regionally based biological criteria in Texas, in Davis, W.S., and Simon, T.P., eds., Biological assessment and criteria-Tools for water resource planning and decision making: CRC Press, 415 p.

Howells, R.G., 1997, Distributional surveys of freshwater bivalves in Texas-Progress report for 1996: Austin, Tex., Texas Parks and Wildlife Department, Inland Fisheries Division, Management Data Series 144, 52 p. 
Hubbs, Clark, 1957, Distributional patterns of Texas freshwater fishes: The Southwestern Naturalist, v. 2, no. 2-3, p. 89-104.

1995, Springs and spring runs as unique aquatic systems: Copeia, v. 4, p. 989-991.

Hubbs, Clark, Edwards, R.J., and Garrett, G.P., 1991, An annotated checklist of the freshwater fishes of Texas, with keys to identification of species: Texas Journal of Science, Special Supplement, v. 43, p. 1-56.

Hubbs, Clark, Kuehne, R.A., and Ball, J.C., 1953, The fishes of the upper Guadalupe River, Texas: Texas Journal of Science, v. 5, no. 2, p. 216-244.

Hynes, H.B.N., 1960, The biology of polluted waters: Liverpool University Press, 202 p.

1970, The ecology of running waters: University of Toronto Press, 555 p.

Jasper, S.K., and Vogtsberger, R.C., 1996, First Texas records of five genera of aquatic beetles (Coleoptera: Noteridae, Dytiscidae, Hydrophilidae) with habitat notes: Entomological News, v. 107, no. 1, p. 49-60.

Kane, S., 1995, Effects of a textile mill effluent and a low water dam on benthic macroinvertebrate community structure of the Guadalupe River in Comal County, Texas: San Marcos, Tex., Southwest Texas State University, M.S. thesis, 65 p.

Karr, J.R., 1995, Protecting aquatic ecosystems-Clean water is not enough, in Davis, W.S., and Simon, T.P., eds., Biological assessment and criteria-Tools for water resource planning and decision making: CRC Press, p. 7-13.

Kastning, E.H., 1983, Relict caves as evidence of landscape and aquifer evolution in a deeply dissected carbonate terrain-Southwest Edwards Plateau, Texas, U.S.A., in Back, William, and LaMoreaux, P.E., eds., V.T. Stringfield Symposium, Processes in Karst Hydrology: Journal of Hydrology, v. 61, p. 89-112.

Kelsey, T., 1997, Fish community structure and water quality assessment (index of biotic integrity) of the San Marcos River, Texas: San Marcos, Tex., Southwest Texas State University, M.S. thesis, 98 p.

Kent, D.H., 1971, The effects of a deep storage reservoir on the benthic macroinvertebrate community: San Marcos, Tex., Southwest Texas State University, M.S. thesis, $75 \mathrm{p}$.

Lang, J.W., 1954, Ground-water resources of the San Antonio area, Texas-A progress report of current studies: Texas Board of Water Engineers Bulletin 5412, 30 p.

Langecker, T.G., and Longley, Glenn, 1993, Morphological adaptations of the Texas blind catfishes Trogloglanis pattersoni and Satan eurystomus (Siluriformes: Ictaluridae) to their underground environment: Copeia, v. 93 , no. 4, p. 976-986.
Lemke, D.E., 1989, Aquatic macrophytes of the upper San Marcos River, Hays County, Texas: The Southwestern Naturalist, v. 34, no. 2, p. 289-291.

Lewis, J.J., 1983, The assignment of the Texas troglobitic water slater Caecidotea pilus to the genus Lirceolus, with an amended diagnosis of the genus (Crustacea: Isopoda: Asellidae): Proceedings of the Biological Society of Washington, v. 96, no. 1, p. 145-148.

Lewis, J.J., and Bowman, T.E., 1996, The subterranean asellids of Texas (Crustacea: Isopoda: Asellidae): Proceedings of the Biological Society of Washington, v. 109 , no. 3 , p. 482-500.

Lindholm, J.J.T., 1979, The gastropods of the upper San Marcos River and their trematode parasites: San Marcos, Tex., Southwest Texas State University, M.S. thesis, $73 \mathrm{p}$.

Livingston, P.P., 1947, Ground-water resources of Bexar County, Texas: Texas Board of Water Engineers Miscellaneous Publication, $240 \mathrm{p}$.

Longley, Glenn, 1981, The Edwards aquifer-Earth's most diverse groundwater ecosystem: International Journal of Speleology, v. 11, no. 1-2, p. 123-128.

1986, The biota of the Edwards aquifer and the implications for paleozoogeography, in Abbott, P.L., and Woodruff, C.M., Jr., The Balcones escarpment-Geology, hydrology, ecology, and social development in central Texas: San Antonio, Tex., Annual Meeting, Geological Society of America, p. 51-54.

1992, The subterranean aquatic ecosystem of the Balcones fault zone Edwards aquifer in Texas-Threats from overpumping, in First International Conference on Ground Water Ecology, Tampa, Fla., Proceedings: Bethesda, Md., U.S. Environmental Protection Agency, American Water Resources Association, p. 291-300.

Longley, Glenn, Cox, K., Phillips, G., and Miller, J., 1996, Environmental study of proposed diversion sites G-10 and G-14 on the Guadalupe River: San Marcos, Tex., Southwest Texas State University, Edwards Aquifer Research and Data Center, Texas Water Development Board Contract 95-483-113.

Maclay, R.W., and Rettman, P.L., 1973, Regional specific yield of the Edwards aquifer and associated limestones in the San Antonio, Texas, area: U.S. Geological Survey Open-File Report 73-172, 14 p. [Also published as Edwards Underground Water District Report, 10 p., 1973.]

Maclay, R.W., and Small, T.A., 1976, Progress report on geology of the Edwards aquifer, San Antonio area, Texas, and preliminary interpretation of borehole geophysical and laboratory data on carbonate rocks: U.S. Geological Survey Open-File Report 76-627, 65 p.

Menard, J.A., 1995, Bibliography of the Edwards aquifer, Texas, through 1993: U.S. Geological Survey Open-File Report 95-336, 75 p. 
Mench, P.A., 1978, Diagenesis related to Miocene faulting in the Edwards aquifer, San Antonio area, Texas: Geological Society of America, Abstracts with Program (South Central Section), v. 10, no. 1, p. 22.

Miller, R.R., Williams, J.D., and Williams J.E., 1989, Extinctions of North American fishes during the past century: Fisheries, v. 14, no. 6, p. 22-38.

Neck, R.W., 1984, Occurrence of the striped ramshorn snail, Marisa cornuarietis, in central Texas (Ampullariidae): Nautilus, v. 98, no. 3, p. 119-120.

Nelson, J.N., 1993, Population size, distribution, and life history of Eurycea nana in the San Marcos River: San Marcos, Tex., Southwest Texas State University, M.S. thesis, $73 \mathrm{p}$.

Obenoskey, J.R., 1997, Distribution, abundance and feeding preferences of the crayfish, Procambarus clarkii, in Landa Lake, Comal County, Texas: San Marcos, Tex., Southwest Texas State University, M.S. thesis, 23 p.

Omernik, J.M., 1987, Ecoregions of the conterminous United States: Annals of the Association of American Geographers, v. 77, scale 1:7,500,000, p. 118-125.

Ono, R.D., Williams, J.D., and Wagner, Anne, 1983, Vanishing fishes of North America: Washington, D.C., Stone Wall Press, Inc., 257 p.

Owen, J.M., 1996, Seasonal and longitudinal changes in functional feeding group composition of benthic macroinvertebrates in the San Marcos River, Texas: San Marcos, Tex., Southwest Texas State University, M.S. thesis, $30 \mathrm{p}$.

Pearson, F.J., Jr., and Rettman, P.L., 1976, Geochemical and isotopic analyses of waters associated with the Edwards Limestone aquifer, central Texas: San Antonio, Tex., Edwards Underground Water District Report, 35 p.

Pearson, F.J., Jr., Rettman, P.L., and Wyerman, T.A., 1975, Environmental tritium in the Edwards aquifer, central Texas, 1963-71: U.S. Geological Survey Open-File Report 74-362, 36 p.

Petitt, B.M., Jr., and George, W.O., 1956, Ground-water resources of the San Antonio area, Texas: Texas Board of Water Engineers Bulletin 5608, v. 1, 85 p.; v. 2, pt. 1, 255 p.; pt. 2, 288 p.; pt. 3, 231 p.

Poulson, T.L., and White, W.B., 1969, The cave environment: Science, v. 165, no. 3897, p. 971-981.

Power, Paula, 1996, Direct and indirect effects of floating vegetation mats on Texas wild rice (Zizania texana): The Southwest Naturalist, v. 41, no. 4, p. 462-464.

Power, Paula, and Fonteyn, P.J., 1995, Effects of oxygen concentration and substrate on seed germination and seedling growth of Texas wild rice (Zizania texana): The Southwestern Naturalist, v. 40, no. 1, p. 1-4.

Puente, Celso, 1974, Records of precipitation, water levels, and ground-water recharge to the Edwards and associated limestones, San Antonio area, Texas, 1972-73: San
Antonio, Tex., Edwards Underground Water District Bulletin 33, 12 p.

1976, Statistical analysis of water-level, springflow, and streamflow data for the Edwards aquifer in southcentral Texas: U.S. Geological Survey Open-File Report 76-393, 52 p. [Also published as Edwards Underground Water District Report, 58 p.]

Rappmund, R.A., 1975, Ground-water discharge from the Edwards and associated limestones, San Antonio area, Texas, 1974: San Antonio, Tex., Edwards Underground Water District Bulletin 34, 8 p.

1976, Ground-water discharge from the Edwards and associated limestones, San Antonio area, Texas, 1975: San Antonio, Tex., Edwards Underground Water District Bulletin 35, 7 p.

1977, Ground-water discharge from the Edwards and associated limestones, San Antonio area, Texas, 1976: San Antonio, Tex., Edwards Underground Water District Bulletin 36, 8 p.

Rathburn, H.D., 1976, Intensive surface water monitoring survey for segment no. 1906-Leon Creek: Austin, Tex., Texas Water Quality Board, Field Operations Division, Report IMS-45.

Reeves, R.D., 1976, Chemical and bacteriological quality of water at selected sites in the San Antonio area, Texas August 1968-January 1975: San Antonio, Tex., Edwards Underground Water District Report, 122 p.

Reeves, R.D., Rawson, Jack, and Blakey, J.F., 1972, Chemical and bacteriological quality of water at selected sites in the San Antonio area, Texas, August 1968-April 1972: San Antonio, Tex., Edwards Underground Water District Report, 63 p.

Resh, V.H., Myers, M.J., and Hannaford, M.J., 1996, Macroinvertebrates as biotic indicators of environmental quality, in Hauer, F.R., and Lamberti, G.A., eds., Methods in stream ecology: San Diego, Calif., Academic Press, 674 p.

Respess, R.O., 1986, Intensive survey of Blanco River segment 1809, June 3-7, 1985: Austin, Tex., Texas Water Commission, Report IS-86-04, 73 p.

Rettman, P.L., 1969, Records of wells and springs, San Antonio area, Texas: San Antonio, Tex., Edwards Underground Water District Report, 28 p.

Richardson, L.R., and Gold, J.R., 1995, Evolution of the Cyprinella lutrensis species-complex-II. Systematics and biogeography of the Edwards Plateau shiner, Cyprinella lepida: Copeia, v. 1, p. 28-37.

Richerson, J.V., 1982, Species diversity of macroinvertebrates in Cibolo Creek in Shafter, Texas, in Davis, J.R., ed., Proceedings of the Symposium on Recent Benthological Investigations in Texas and Adjacent States: Texas Academy of Science, Aquatic Sciences Section, p. 113-122. 
Robins, C.H., 1971, Ecology of the introduced snail, Marisa cornuarietis (Ampullariidae) in Dade County, Florida. The Biologist, v. 53, p. 136-152.

Rosenberg, D.M., and Resh, V.H., 1993, Introduction to freshwater biomonitoring and benthic macroinvertebrates, in Rosenberg, D.M., and Resh, V.H., eds., Freshwater biomonitoring and benthic macroinvertebrates: New York, Chapman and Hall, p. 1-9.

San Antonio River Authority, 1996, Evaluation of aquatic ecosystems of streams in the San Antonio River watershed based on rapid bioassessment protocols: San Antonio River Authority, Environmental Services Division, 186 p.

Sarbu, S.M., Kane, T.C., and Kinkle, B.K., 1996, A chemoautotrophically-based cave ecosystem: Science, v. 272, no. 5,270, p. 1,953-1,955.

Schenck, J.R., 1975, Ecology of the fountain darter, Etheostoma fonticola, (Osteichthyes: Percidae): San Marcos, Tex., Southwest Texas State University, M.S. thesis, $100 \mathrm{p}$.

Schenck, J.R., and Whiteside, B.G., 1976, Distribution, habitat preference, and population size estimate of Etheostoma fonticola (Osteichthyes: Percidae): Copeia, v. 76 , no. 4 , p. 697-703.

1977a, Food habits and feeding behavior of the fountain darter, Etheostoma fonticola (Osteichthyes: Percidae): The Southwestern Naturalist, v. 21, no. 4, p. 487492.

1977b, Reproduction, fecundity, sexual dimorphism and sex ratio of Etheostoma fonticola (Osteichthyes: Percidae): American Midland Naturalist, v. 98, no. 2, p. 365-375.

Schultz, A.L., 1994, 1994 review and update of the position of the Edwards aquifer freshwater/saline-water interface from Uvalde to Kyle, Texas: Edwards Underground Water District Report 94-05, 31 p.

Sculthorpe, C.D., 1967, The biology of aquatic vascular plants: New York, St. Martin's Press, 610 p.

Short, R.A., 1982, Diel changes in physiochemical and biological parameters in the Guadalupe River, Texas, in Davis, J.R., ed., Proceedings of the Symposium on Recent Benthological Investigations in Texas and Adjacent States: Texas Academy of Science, Aquatic Sciences Section, p. 149-159.

Short, R.A., and Smith, S.L., 1989, Seasonal comparison of leaf processing in a Texas stream: American Midland Naturalist, v. 121, no. 2, p. 219-224.

Sieh, T.W., 1975, Edwards (Balcones fault zone) aquifer testwell drilling investigation: Austin, Tex., Texas Water Development Board, 117 p.

Simon, T.P., Brandt, T.M., Graves, K.G., and Whiteside, B.G., 1995, Ontogeny and description of eggs, larvae, and early juveniles of the fountain darter, Etheostoma fonticola: The Southwestern Naturalist, v. 40, no. 2, p. 208-215.

Solanik, D.C., 1996, Longitudinal and seasonal variation in macroinvertebrate taxonomic and functional feeding group composition of a central Texas stream: San Marcos, Tex., Southwest Texas State University, M.S. thesis, $48 \mathrm{p}$.

Stanley, E.H., 1986, The ecology of mayflies (Ephemeroptera) in the Guadalupe River Basin, Texas: San Marcos, Tex., Southwest Texas State University, M.S. thesis, $94 \mathrm{p}$.

Stanley, E.H., and Short, R.A., 1988, Temperature effects on warmwater stream insects-A test of the thermal equilibrium hypothesis: Oikos, v. 51, no. 3, p. 313-320.

Staton, L.L., 1992, Assessment of changes in the aquatic macrophyte community in the upper San Marcos River: San Marcos, Tex., Southwest Texas State University, M.S. thesis, $74 \mathrm{p}$.

Stock, J.H., and Longley, Glenn, 1981, The generic status and distribution of Monodella texana Maguire, the only known North American Thermosbaenacean: Proceedings of the Biological Society of Washington, v. 94, no. 2, p. 569-578.

Strayer, D.L., 1994, Limits to biological distributions in groundwater, in Gilbert, J., Danielopol, D., and Stanford, J., eds., Groundwater ecology: San Diego, Calif., Academic Press, p. 287-310.

Strenth, N.E., 1976, A review of the systematics and zoogeography of the freshwater species of Palaemonetes Heller of North America: Smithsonian Contributions to Zoology, no. 228, 24 p.

Strenth, N.E., and Longley, Glenn, 1990, Reproductive patterns of the subterranean shrimp Palaemonetes antrorum Benedict (Decapoda, Palaemonidae) from Central Texas: Stygologia, v. 5, no. 4, p. 221-224.

Strenth, N.E., Norton, J.D., and Longley, Glenn, 1988. The larval development of the subterranean shrimp Palaemonetes antrorum Benedict (Decapoda, Palaemonidae) from Central Texas: Stygologia, v. 4, no. 4, p. 363-370.

Sweet, S.S., 1982, A distribution analysis of epigean populations of Eurycea neotenes in central Texas, with comments on the origin of troglobitic populations: Herpetologica, v. 38, no. 3, p. 430-444.

Taylor, R.L., 1995, Biological and associated water-quality data for lower Olmos Creek and upper San Antonio River, San Antonio, Texas, March-October 1990: U.S. Geological Survey Open-File Report 95-103, 73 p.

Taylor, R.L., and Ferreira, R.F., 1995, Biological and associated water-quality data for lower Olmos Creek and upper San Antonio River, San Antonio, Texas, April-September 1989: U.S. Geological Survey Open-File Report 95-148, 68 p. 
Terre, D.R., and Magnelia, S.J., 1996, Survey report for the Guadalupe River in Kendall and Comal Counties, Texas, 1995: Texas Parks and Wildlife Department, prepared for Federal Aid in Sport Fish Restoration Act Project F-30-R-21.

1997, Statewide freshwater fisheries monitoring and management program-Survey report for Canyon Reservoir: Texas Parks and Wildlife Department, prepared for Federal Aid In Sport Fish Restoration Act Project F-30-R-21.

Terrell, E.E., Emery, W.H.P., and Beaty, H.E., 1978, Observations on Zizania texana (Texas wild rice), an endangered species: Bulletin of the Torrey Botanical Club, v. 105, no. 1 , p. 50-57.

Texas System of Natural Laboratories, Inc., 1994, Freshwater and marine fishes of Texas and the northwestern Gulf of Mexico-Taxonomic and distributional inventory with bibliography: Austin, Tex., Texas System of Natural Laboratories, Laboratory Index Series No. FTX/NWGM-94, 270 p.

Thornhill, P.D., Harden, R.W., and Nevola, Roger, 1988, The Edwards aquifer - Underground river of Texas: Seguin, Tex., Guadalupe-Blanco River Authority, 63 p.

Tiemann, S.G., 1992, Life history patterns and diversity of caddisflies (Trichoptera) in four streams in the Guadalupe River Basin with contrasting temperature and flow regimes: San Marcos, Tex., Southwest Texas State University, M.S. thesis, 72 p.

Tomme, M.H., 1974, Intensive surface water monitoring survey for segment no. 1902-Cibolo Creek: Austin, Tex., Texas Water Quality Board, Field Operations Division, Report IMS-38.

Trebatoski, B., 1991, Guadalupe River toxicity assessmentInvestigation of the potential impact of a domestic wastewater treatment facility upon the Guadalupe River: Texas Water Commission, Report LP 91-04, 33 p.

Twidwell, S.R., 1975, Intensive surface water monitoring survey for segment no. 1901—San Antonio River: Austin, Tex., Texas Water Quality Board, Field Operations Division, Report IMS-30, 32 p.

1976, Intensive surface water monitoring survey for segment no. 1903-Medina River: Austin, Tex., Texas
Water Quality Board, Field Operations Division, Report IMS-46, $56 \mathrm{p}$.

1984, Intensive survey of San Antonio River segment 1901: Austin, Tex., Texas Department of Water Resources, Water Quality Assessment Unit, Report IS-59, 46 p.

1987, Intensive survey of the Guadalupe River, segment 1806: Austin, Tex., Texas Water Commission, Report IS-87-02, 46 p.

Twidwell, S.R., and David, J.R., 1987, Intensive surveys of San Antonio River segments 1901 and 1911, June 6, 1984-May 16, 1985: Austin, Tex., Texas Water Commission, Report IS-87-04, 87 p.

U.S. Environmental Protection Agency, 1996, Biological criteria-Technical guidance for streams and small rivers: Washington, D.C., U.S. Environmental Protection Agency, EPA 822-B-96-001.

U.S. Fish and Wildlife Service, 1995, The San Marcos and Comal Springs and associated aquatic ecosystems recovery plan (revised): Albuquerque, N. Mex., 93 p.

1997, Endangered and threatened wildlife and plants; final rule to list three aquatic invertebrates in Comal and Hays Counties, Texas, as endangered: Federal Register, v. 62 , no. 243,50 CFR pt. 17 , p. 66,295-66,304.

van der Leeden, Frits, Troise, F.L., and Todd, D.K., 1990, The water encyclopedia: Chelsea, Mich., Lewis Publishers, $808 \mathrm{p}$.

Wanakule, Nisai, 1988, Regression analysis of the San Marcos springflows and water levels of the index well in San Antonio: San Marcos, Tex., Edwards Aquifer Research and Data Center, R1-88, 34 p.

Webster, J.R., and Benfield, E.F., 1986, Vascular plant breakdown in freshwater ecosystems: Annual Review of Ecological Systematics, v. 17, p. 567-594.

Young, F.N., and Longley, Glenn, 1976, A new subterranean aquatic beetle from Texas (Coleoptera: DytiscidaeHydroporinae): Annals of the Entomological Society of America, v. 69, no. 5, p. 787-792.

Young, W.C., Whiteside, B.G., Longley, G., and Carter, N.E., 1973, The Guadalupe-San Antonio-Nueces River Basin Project-Review of existing biological data: Final Report to Texas Water Development Board, 400 p. 
Table 1. Literature citations for biological surveys and field studies in the South-Central Texas study unit, Texas

[USGS, U.S. Geological Survey]

\begin{tabular}{|c|c|c|c|c|c|c|c|c|c|c|c|c|c|c|c|c|}
\hline \multirow[b]{2}{*}{$\begin{array}{l}\text { No. } \\
\text { (figs. } \\
2-5)\end{array}$} & \multirow[b]{2}{*}{ Citation } & \multicolumn{9}{|c|}{ Type of study } & \multicolumn{6}{|c|}{ Ecoregion } \\
\hline & & $\begin{array}{l}\text { Verte- } \\
\text { brates }\end{array}$ & $\begin{array}{c}\text { Inverte- } \\
\text { brates }\end{array}$ & Plants & $\begin{array}{l}\text { Troglo- } \\
\text { bites }\end{array}$ & $\begin{array}{l}\text { Non- } \\
\text { indig- } \\
\text { enous }\end{array}$ & $\begin{array}{c}\text { Habi- } \\
\text { tat }\end{array}$ & $\begin{array}{l}\text { Edwards } \\
\text { aquifer }\end{array}$ & $\begin{array}{l}\text { Species } \\
\text { of con- } \\
\text { cern }\end{array}$ & $\begin{array}{c}\text { Water } \\
\text { chem- } \\
\text { istry }\end{array}$ & $\begin{array}{l}\text { Edwards } \\
\text { Plateau }\end{array}$ & $\begin{array}{l}\text { Texas } \\
\text { Black- } \\
\text { land } \\
\text { Prairies }\end{array}$ & \begin{tabular}{|l|} 
East \\
Central \\
Texas \\
Plains
\end{tabular} & $\begin{array}{l}\text { Western } \\
\text { Gulf } \\
\text { Coastal } \\
\text { Plain }\end{array}$ & $\begin{array}{l}\text { South- } \\
\text { ern } \\
\text { Texas } \\
\text { Plains }\end{array}$ & Subject \\
\hline 1 & $\begin{array}{r}\text { Anderson and } \\
\text { others, } 1995\end{array}$ & $\mathrm{X}$ & & & & & & & & & $\mathrm{X}$ & $\mathrm{X}$ & $\mathrm{X}$ & & & $\begin{array}{l}\text { Examination of changes in Texas fish } \\
\text { community structure over } 30 \text {-year period. }\end{array}$ \\
\hline 2 & $\begin{array}{r}\text { Angerstein and } \\
\text { Lemke, } 1994\end{array}$ & & & $\mathrm{X}$ & & $\mathrm{X}$ & & & & & $\mathrm{X}$ & & & & & $\begin{array}{l}\text { First collections of Hygrophila polysperma, } \\
\text { a potentially noxious aquatic weed, } \\
\text { reported from Comal and San Marcos } \\
\text { Rivers, central Texas. }\end{array}$ \\
\hline 3 & $\begin{array}{l}\text { Barr and Spangler, } \\
1992\end{array}$ & & $\mathrm{X}$ & & $\mathrm{X}$ & & & $\mathrm{X}$ & & & $\mathrm{X}$ & & & & & $\begin{array}{l}\text { Description of aquatic beetle, Stygoparnus } \\
\text { comalensis, and comparison with dryopid } \\
\text { genus Helichus. First member of } \\
\text { Dryopidae reported from subterranean } \\
\text { waters. }\end{array}$ \\
\hline 4 & Barra, 1976 & & $\mathrm{X}$ & & & & & & & & & $\mathrm{X}$ & & & & $\begin{array}{l}\text { Power-plant effluent effect on } \\
\text { macroinvertebrate diversity in Calaveras } \\
\text { Lake. }\end{array}$ \\
\hline 5 & Bayer, 1975 & & $\mathrm{X}$ & & & & & & & & $\mathrm{X}$ & $\mathrm{X}$ & $\mathrm{X}$ & $\mathrm{X}$ & & $\begin{array}{l}\text { Description of dragonfly (Anisoptera) } \\
\text { nymphs in lentic and lotic areas, } \\
\text { Guadalupe River Basin. }\end{array}$ \\
\hline 6 & $\begin{array}{l}\text { Bayer and others, } \\
1992\end{array}$ & $\mathrm{X}$ & $\mathrm{X}$ & & & & $\mathrm{X}$ & & & $\mathrm{X}$ & $\mathrm{X}$ & $\mathrm{X}$ & & & $\mathrm{X}$ & Classification of smaller streams in Texas. \\
\hline 7 & Bowles, 1994 & & $\mathrm{X}$ & & & & & & & & & $\mathrm{X}$ & & & & Survey of caddisflies of Comal Springs. \\
\hline 8 & $\begin{array}{l}\text { Bowles and Short, } \\
1988\end{array}$ & $\mathrm{X}$ & $\mathrm{X}$ & & & & & & & $\mathrm{X}$ & $\mathrm{X}$ & & & & & $\begin{array}{l}\text { Effect of fish predation on } \\
\text { macroinvertebrate drift in Honey Creek. }\end{array}$ \\
\hline 9 & $\begin{array}{l}\text { Bowman and } \\
\text { Jensen, } 1977\end{array}$ & & $\mathrm{X}$ & & & & & & & $\mathrm{X}$ & & & & $\mathrm{X}$ & & $\begin{array}{l}\text { Collection of field data and water samples } \\
\text { for chemical analysis at seven sites on } \\
\text { Nueces River. }\end{array}$ \\
\hline 10 & Bradsby, 1994 & $\mathrm{X}$ & $\mathrm{X}$ & $\mathrm{X}$ & & & $\mathrm{X}$ & & & & & $\mathrm{X}$ & & & & $\begin{array}{l}\text { Impact of recreation on upper San Marcos } \\
\text { River. }\end{array}$ \\
\hline 11 & Brown, 1953 & $\mathrm{X}$ & & & & $\mathrm{X}$ & & & & & & $\mathrm{X}$ & & & & $\begin{array}{l}\text { List of introduced fish species in San } \\
\text { Marcos, Comal, and San Antonio Springs. }\end{array}$ \\
\hline 12 & Buzan, 1982a & & $\mathrm{X}$ & & & & & & & $\mathrm{x}$ & $\mathrm{X}$ & $\mathrm{X}$ & & & & Two surveys in Cibolo Creek, 1980. \\
\hline 13 & Buzan, 1982b & $\mathrm{X}$ & $\mathrm{X}$ & & & & & & & $\mathrm{X}$ & $\mathrm{X}$ & $\mathrm{X}$ & & & & Two surveys in Salado Creek, 1981. \\
\hline 14 & Cover, 1980 & & $\mathrm{X}$ & & & & & & & & & $\mathrm{X}$ & & & & Mayfly drift in San Marcos River. \\
\hline 15 & $\begin{array}{l}\text { Crowe and Sharp, } \\
1997\end{array}$ & $\mathrm{X}$ & $\mathrm{X}$ & $\mathrm{X}$ & & $\mathrm{X}$ & $\mathrm{X}$ & $\mathrm{X}$ & $\mathrm{X}$ & $\mathrm{X}$ & & $\mathrm{X}$ & & & & $\begin{array}{l}\text { Delineation of } 18 \text { distinctive habitats for } \\
\text { endangered fountain darter in Comal } \\
\text { Springs/River system. }\end{array}$ \\
\hline
\end{tabular}


Table 1. Literature citations for biological surveys and field studies in the South-Central Texas study unit, Texas-Continued

\begin{tabular}{|c|c|c|c|c|c|c|c|c|c|c|c|c|c|c|c|c|}
\hline \multirow[b]{2}{*}{$\begin{array}{c}\text { No. } \\
\text { (figs. } \\
2-5)\end{array}$} & \multirow[b]{2}{*}{ Citation } & \multicolumn{9}{|c|}{ Type of study } & \multicolumn{6}{|c|}{ Ecoregion } \\
\hline & & $\begin{array}{l}\text { Verte- } \\
\text { brates }\end{array}$ & $\begin{array}{l}\text { Inverte- } \\
\text { brates }\end{array}$ & Plants & $\begin{array}{c}\text { Troglo- } \\
\text { bites }\end{array}$ & $\begin{array}{l}\text { Non- } \\
\text { indig- } \\
\text { enous }\end{array}$ & $\begin{array}{c}\text { Habi- } \\
\text { tat }\end{array}$ & $\begin{array}{l}\text { Edwards } \\
\text { aquifer }\end{array}$ & $\begin{array}{c}\text { Species } \\
\text { of con- } \\
\text { cern }\end{array}$ & $\begin{array}{c}\text { Water } \\
\text { chem- } \\
\text { istry }\end{array}$ & $\begin{array}{l}\text { Edwards } \\
\text { Plateau }\end{array}$ & $\begin{array}{l}\text { Texas } \\
\text { Black- } \\
\text { land } \\
\text { Prairies }\end{array}$ & \begin{tabular}{|c|} 
East \\
Central \\
Texas \\
Plains
\end{tabular} & $\begin{array}{l}\text { Western } \\
\text { Gulf } \\
\text { Coastal } \\
\text { Plain }\end{array}$ & $\begin{array}{l}\text { South- } \\
\text { ern } \\
\text { Texas } \\
\text { Plains }\end{array}$ & Subject \\
\hline 16 & Davis, 1975 & $\mathrm{X}$ & & & & & & & & & & $\mathrm{X}$ & & & & $\begin{array}{l}\text { Survey of parasitic worms of western } \\
\text { mosquitofish, Gambusia affinis, near San } \\
\text { Marcos. }\end{array}$ \\
\hline 17 & Davis, 1980 & $\mathrm{X}$ & & & & & & & & & $\mathrm{X}$ & & & & & $\begin{array}{l}\text { Comparison of growth of largemouth bass } \\
\text { from selected areas of Canyon Reservoir. }\end{array}$ \\
\hline 18 & Davis, 1982 & & $\mathrm{X}$ & & & & & & & & $\mathrm{X}$ & $\mathrm{X}$ & & & & $\begin{array}{l}\text { Benthic macroinvertebrate diversity of three } \\
\text { subreaches of Cibolo Creek. }\end{array}$ \\
\hline 19 & De La Cruz, 1978 & & $\mathrm{X}$ & & & & & & & $\mathrm{X}$ & & & & & $\mathrm{X}$ & $\begin{array}{l}\text { Collection of physical, chemical, and } \\
\text { biological data for Nueces River. }\end{array}$ \\
\hline 20 & De La Cruz, 1994 & $\mathrm{X}$ & $\mathrm{X}$ & & & & $\mathrm{X}$ & & & $\mathrm{X}$ & & $\mathrm{X}$ & & & & $\begin{array}{l}\text { Biosurvey for impact assessment of lower } \\
\text { Leon Creek using modified Rapid } \\
\text { Bioassessment Protocols III and V. }\end{array}$ \\
\hline 21 & Devall, 1940 & & & $\mathrm{X}$ & & & $\mathrm{X}$ & & & $\mathrm{X}$ & & & & & & $\begin{array}{l}\text { Macrophytes of Spring Lake (San Marcos } \\
\text { Springs). }\end{array}$ \\
\hline 22 & $\begin{array}{r}\text { Epperson and } \\
\text { Short, } 1987\end{array}$ & & $\mathrm{X}$ & & & & & & & & & & & & & $\begin{array}{l}\text { Annual production of the hellgrammite, } \\
\text { Corydalus cornutus, in Guadalupe River. }\end{array}$ \\
\hline 23 & $\begin{array}{l}\text { Espey, Huston and } \\
\text { Associates, Inc., } \\
1983\end{array}$ & $\mathrm{X}$ & $\mathrm{X}$ & & & & & & & $\mathrm{X}$ & & $\mathrm{X}$ & $\mathrm{X}$ & & & $\begin{array}{l}\text { Examination of aquatic habitats of Medina } \\
\text { and San Antonio Rivers. }\end{array}$ \\
\hline 24 & Ezell, 1982 & & $\mathrm{X}$ & & & & & & & $\mathrm{X}$ & $\mathrm{X}$ & $\mathrm{X}$ & & & & $\begin{array}{l}\text { Two surveys, } 1979 \text {-collection of physical, } \\
\text { chemical, and biological data for Cibolo } \\
\text { Creek. }\end{array}$ \\
\hline 25 & Findeisen, 1997 & $\mathrm{X}$ & & & & & $\mathrm{X}$ & & & $\mathrm{X}$ & & & $\mathrm{X}$ & & & $\begin{array}{l}\text { Determination of fish species composition, } \\
\text { biotic integrity, sensitivity of index of } \\
\text { biotic integrity, and assessment of fish } \\
\text { habitat use on lower San Antonio River at } \\
\text { three different flows. }\end{array}$ \\
\hline 26 & Garrett, 1991 & $\mathrm{X}$ & & & & $\mathrm{X}$ & & & $\mathrm{X}$ & & & & & & & $\begin{array}{l}\text { Guidelines for management of Guadalupe } \\
\text { bass. }\end{array}$ \\
\hline 27 & Gonzales, 1988 & $\mathrm{X}$ & & & & & & & & $\mathrm{X}$ & $\mathrm{X}$ & $\mathrm{X}$ & & & & $\begin{array}{l}\text { Assessment of biotic integrity of upper San } \\
\text { Antonio River using fish-community } \\
\text { composition and structure. }\end{array}$ \\
\hline 28 & $\begin{array}{l}\text { C.A. Hartmann, } \\
\text { USGS, written } \\
\text { commun., } 1995\end{array}$ & & $\mathrm{X}$ & $\mathrm{X}$ & & & & & & $\mathrm{X}$ & $\mathrm{X}$ & $\mathrm{X}$ & & & & $\begin{array}{l}\text { Biological collections from USGS 1992-95 } \\
\text { study of upper San Antonio River and } \\
\text { Olmos and Salado Creeks. }\end{array}$ \\
\hline 29 & $\begin{array}{l}\text { Hershler and } \\
\text { Longley, 1986a }\end{array}$ & & $\mathrm{X}$ & & $\mathrm{X}$ & & & $\mathrm{X}$ & & & $\mathrm{X}$ & & & & & $\begin{array}{l}\text { Description of Hadoceras taylori, a phreatic } \\
\text { snail from three localities in Real County. }\end{array}$ \\
\hline
\end{tabular}


Table 1. Literature citations for biological surveys and field studies in the South-Central Texas study unit, Texas-Continued

\begin{tabular}{|c|c|c|c|c|c|c|c|c|c|c|c|c|c|c|c|c|}
\hline \multirow[b]{2}{*}{$\begin{array}{l}\text { No. } \\
\text { (figs. } \\
2-5)\end{array}$} & \multirow[b]{2}{*}{ Citation } & \multicolumn{9}{|c|}{ Type of study } & \multicolumn{6}{|c|}{ Ecoregion } \\
\hline & & $\begin{array}{l}\text { Verte- } \\
\text { brates }\end{array}$ & $\begin{array}{c}\text { Inverte- } \\
\text { brates }\end{array}$ & Plants & $\begin{array}{l}\text { Troglo- } \\
\text { bites }\end{array}$ & $\begin{array}{l}\text { Non- } \\
\text { indig- } \\
\text { enous }\end{array}$ & $\begin{array}{c}\text { Habi- } \\
\text { tat }\end{array}$ & $\begin{array}{c}\text { Edwards } \\
\text { aquifer }\end{array}$ & $\begin{array}{l}\text { Species } \\
\text { of con- } \\
\text { cern }\end{array}$ & $\begin{array}{c}\text { Water } \\
\text { chem- } \\
\text { istry }\end{array}$ & $\begin{array}{l}\text { Edwards } \\
\text { Plateau }\end{array}$ & $\begin{array}{l}\text { Texas } \\
\text { Black- } \\
\text { land } \\
\text { Prairies }\end{array}$ & $\begin{array}{l}\text { East } \\
\text { Central } \\
\text { Texas } \\
\text { Plains }\end{array}$ & $\begin{array}{l}\text { Western } \\
\text { Gulf } \\
\text { Coastal } \\
\text { Plain }\end{array}$ & $\begin{array}{l}\text { South- } \\
\text { ern } \\
\text { Texas } \\
\text { Plains }\end{array}$ & Subject \\
\hline 30 & $\begin{array}{l}\text { Hershler and } \\
\text { Longley, 1986b }\end{array}$ & $\mathrm{X}$ & $\mathrm{X}$ & & $\mathrm{X}$ & & & $\mathrm{X}$ & $\mathrm{X}$ & & $\mathrm{X}$ & & & & & $\begin{array}{l}\text { Systematic analysis of phreatic snails } \\
\text { (hydrobiids) from } 23 \text { localities in south- } \\
\text { central Texas. }\end{array}$ \\
\hline 31 & $\begin{array}{l}\text { Hershler and } \\
\text { Longley, } 1987\end{array}$ & & $\mathrm{X}$ & & $\mathrm{X}$ & & & $\mathrm{X}$ & & & $\mathrm{X}$ & & & & & $\begin{array}{l}\text { Description of new species of cavesnail, } \\
\text { Phreatodrobia coronae, from spring } \\
\text { orifices in southwestern Texas. }\end{array}$ \\
\hline 32 & $\begin{array}{l}\text { Hobbs and Hobbs, } \\
1995\end{array}$ & & $\mathrm{X}$ & & & & & & & & & & & & & $\begin{array}{l}\text { Description of new crayfish for Nueces } \\
\text { River Basin. }\end{array}$ \\
\hline 33 & Howells, 1997 & & $X$ & & & & $X$ & & $X$ & & & & & & & $\begin{array}{l}\text { Documentation of 7,200 unionids collected } \\
\text { from } 232 \text { locations statewide. }\end{array}$ \\
\hline 34 & $\begin{array}{l}\text { Hubbs and others, } \\
1953\end{array}$ & $\mathrm{X}$ & & & & & $\mathrm{X}$ & & & & $\mathrm{X}$ & & & & & Fish survey of upper Guadalupe River. \\
\hline 35 & $\begin{array}{l}\text { Jasper and } \\
\text { Vogtsberger, } \\
1996\end{array}$ & & $\mathrm{X}$ & & & & $\mathrm{X}$ & & & & & & & & & $\begin{array}{l}\text { Descriptions and habitat notes of some } \\
\text { aquatic beetles. }\end{array}$ \\
\hline 36 & Kane, 1995 & & $\mathrm{X}$ & & & & & & & & & $\mathrm{X}$ & & & & $\begin{array}{l}\text { Textile-mill effluent and low-water dam } \\
\text { effects on benthic macroinvertebrate } \\
\text { communities in Guadalupe River. }\end{array}$ \\
\hline 37 & Kelsey, 1997 & $\mathrm{X}$ & & & & & $\mathrm{X}$ & & & & & $\mathrm{X}$ & $\mathrm{X}$ & & & $\begin{array}{l}\text { Index of biotic integrity used to assess water } \\
\text { quality and impacts from point and } \\
\text { nonpoint sources of pollution in San } \\
\text { Marcos River. }\end{array}$ \\
\hline 38 & Kent, 1971 & & $\mathrm{X}$ & & & & & & & & $\mathrm{X}$ & & & & & $\begin{array}{l}\text { Measurement of effects of Canyon Reservoir } \\
\text { on benthic macroinvertebrate } \\
\text { communities of Guadalupe River. }\end{array}$ \\
\hline 39 & Lemke, 1989 & & & $\mathrm{X}$ & & $\mathrm{X}$ & & & $\mathrm{X}$ & & & & & & & $\begin{array}{l}\text { List of aquatic vascular plants in San Marcos } \\
\text { River upstream of Blanco River } \\
\text { confluence. }\end{array}$ \\
\hline 40 & $\begin{array}{l}\text { Lewis and } \\
\quad \text { Bowman, } 1996\end{array}$ & & $X$ & & $X$ & & & & & & $\mathrm{X}$ & & & & & $\begin{array}{l}\text { Classification and collection sites of known } \\
\text { subterranean asellids of Texas. }\end{array}$ \\
\hline 41 & Lindholm, 1979 & & $\mathrm{X}$ & & & & & & & & & $\mathrm{X}$ & & & & $\begin{array}{l}\text { Gastropod survey of upper San Marcos } \\
\text { River. }\end{array}$ \\
\hline 42 & Longley, 1992 & $\mathrm{X}$ & $\mathrm{X}$ & & $\mathrm{X}$ & & $\mathrm{X}$ & $\mathrm{X}$ & $\mathrm{X}$ & & $\mathrm{X}$ & & & & & $\begin{array}{l}\text { Aquatic fauna assemblage in Edwards } \\
\text { aquifer. Examines threats of ground-water } \\
\text { pumping on aquifer organisms. }\end{array}$ \\
\hline 43 & $\begin{array}{l}\text { Longley and } \\
\text { others, } 1996\end{array}$ & $\mathrm{X}$ & $X$ & & & & & & & $X$ & & $X$ & $X$ & & & $\begin{array}{l}\text { Bathymetric, hydrological, habitat, and } \\
\text { biological assessment of potential dam } \\
\text { sites on Guadalupe River. }\end{array}$ \\
\hline
\end{tabular}


Table 1. Literature citations for biological surveys and field studies in the South-Central Texas study unit, Texas-Continued

\begin{tabular}{|c|c|c|c|c|c|c|c|c|c|c|c|c|c|c|c|c|}
\hline \multirow[b]{2}{*}{$\begin{array}{l}\text { No. } \\
\text { (figs. } \\
2-5)\end{array}$} & \multirow[b]{2}{*}{ Citation } & \multicolumn{9}{|c|}{ Type of study } & \multicolumn{6}{|c|}{ Ecoregion } \\
\hline & & $\begin{array}{l}\text { Verte- } \\
\text { brates }\end{array}$ & $\begin{array}{c}\text { Inverte- } \\
\text { brates }\end{array}$ & Plants & $\begin{array}{c}\text { Troglo- } \\
\text { bites }\end{array}$ & $\begin{array}{l}\text { Non- } \\
\text { indig- } \\
\text { enous }\end{array}$ & $\begin{array}{c}\text { Habi- } \\
\text { tat }\end{array}$ & $\begin{array}{l}\text { Edwards } \\
\text { aquifer }\end{array}$ & $\begin{array}{l}\text { Species } \\
\text { of con- } \\
\text { cern }\end{array}$ & $\begin{array}{l}\text { Water } \\
\text { chem- } \\
\text { istry }\end{array}$ & $\begin{array}{l}\text { Edwards } \\
\text { Plateau }\end{array}$ & $\begin{array}{l}\text { Texas } \\
\text { Black- } \\
\text { land } \\
\text { Prairies }\end{array}$ & $\begin{array}{l}\text { East } \\
\text { Central } \\
\text { Texas } \\
\text { Plains }\end{array}$ & $\begin{array}{l}\text { Western } \\
\text { Gulf } \\
\text { Coastal } \\
\text { Plain }\end{array}$ & $\begin{array}{l}\text { South- } \\
\text { ern } \\
\text { Texas } \\
\text { Plains }\end{array}$ & Subject \\
\hline 44 & Neck, 1984 & & $\mathrm{X}$ & $\mathrm{X}$ & & $\mathrm{X}$ & & & & & & $\mathrm{X}$ & & & & $\begin{array}{l}\text { Documentation of invasion of exotic giant } \\
\text { ramshorn snail (Marisa cornuarietis) in } \\
\text { San Marcos River. }\end{array}$ \\
\hline 45 & Nelson, 1993 & $\mathrm{X}$ & & & & & $\mathrm{X}$ & $\mathrm{X}$ & $\mathrm{X}$ & & & & & & & $\begin{array}{l}\text { Population size, distribution, and life history } \\
\text { of San Marcos salamander (Eurycea } \\
\text { nana), San Marcos River. }\end{array}$ \\
\hline 46 & Obenoskey, 1997 & & $\mathrm{X}$ & $\mathrm{X}$ & & $\mathrm{X}$ & $\mathrm{X}$ & & $\mathrm{X}$ & & & $\mathrm{X}$ & & & & $\begin{array}{l}\text { Effect of crayfish, Procambarus clarkii, on } \\
\text { macrophytes and snails in Landa Lake. }\end{array}$ \\
\hline 47 & Owen, 1996 & & $\mathrm{X}$ & & & & & & & & & & & & & $\begin{array}{l}\text { Examination of effectiveness of River } \\
\text { Continuum Concept as a model for } \\
\text { Edwards Plateau streams. }\end{array}$ \\
\hline 48 & Power, 1996 & & & $\mathrm{X}$ & & $\mathrm{X}$ & & & $\mathrm{X}$ & & & & & & & $\begin{array}{l}\text { Potential threat of floating and submerged } \\
\text { drifting aquatic vegetation to Texas wild } \\
\text { rice (Zizania texana). }\end{array}$ \\
\hline 49 & $\begin{array}{l}\text { Power and } \\
\quad \text { Fonteyn, } 1995\end{array}$ & & & $\mathrm{X}$ & & & & & $\mathrm{X}$ & & & & & & & $\begin{array}{l}\text { Determination of substrate preference by } \\
\text { endangered Texas wild rice (Zizania } \\
\text { texana) in Spring Lake. }\end{array}$ \\
\hline 50 & Rathburn, 1976 & & $\mathrm{X}$ & & & & & & & $\mathrm{X}$ & & $\mathrm{X}$ & & & & $\begin{array}{l}\text { Collection of physical, chemical, and } \\
\text { biological data for Leon Creek. }\end{array}$ \\
\hline 51 & Respess, 1986 & & $\mathrm{X}$ & & & & & & & $\mathrm{X}$ & $\mathrm{X}$ & & & & & $\begin{array}{l}\text { Collection of physical, chemical, and } \\
\text { biological data for Blanco River. }\end{array}$ \\
\hline 52 & $\begin{array}{l}\text { Richardson and } \\
\text { Gold, } 1995\end{array}$ & $\mathrm{X}$ & & & & & & & & & & & & $\mathrm{X}$ & & $\begin{array}{l}\text { Examination of samples of plateau shiners } \\
\text { (Cyprinella lepida) collected in Nueces } \\
\text { River Basin for restriction site variation of } \\
\text { mitochondrial DNA. }\end{array}$ \\
\hline 53 & $\begin{array}{c}\text { San Antonio River } \\
\text { Authority, } 1996\end{array}$ & $\mathrm{X}$ & $\mathrm{X}$ & & & & $\mathrm{X}$ & & & $\mathrm{X}$ & $X$ & $\mathrm{X}$ & $\mathrm{X}$ & & & $\begin{array}{l}\text { Evaluation of biological communities as an } \\
\text { indicator parameter for water quality in } \\
\text { San Antonio River watershed. }\end{array}$ \\
\hline 54 & Schenck, 1975 & $\mathrm{X}$ & & & & & & & $\mathrm{X}$ & & & $\mathrm{X}$ & & & & $\begin{array}{l}\text { Ecology of endangered fountain darter in } \\
\text { upper San Marcos River. }\end{array}$ \\
\hline 55 & $\begin{array}{l}\text { Schenck and } \\
\quad \text { Whiteside, } 1976\end{array}$ & $\mathrm{X}$ & & & & & & & $\mathrm{X}$ & & & $\mathrm{X}$ & & & & $\begin{array}{l}\text { Distribution, habitat preference, and } \\
\text { population size estimate of fountain darter } \\
\text { (Etheostoma fonticola) in San Marcos } \\
\text { River. }\end{array}$ \\
\hline 56 & $\begin{array}{l}\text { Schenck and } \\
\text { Whiteside, } \\
\text { 1977a }\end{array}$ & $\mathrm{X}$ & & & & & & & $X$ & & & $\mathrm{X}$ & & & & $\begin{array}{l}\text { Food habits and feeding behavior of } \\
\text { endangered fountain darter (Etheostoma } \\
\text { fonticola) in San Marcos River. }\end{array}$ \\
\hline
\end{tabular}


Table 1. Literature citations for biological surveys and field studies in the South-Central Texas study unit, Texas-Continued

\begin{tabular}{|c|c|c|c|c|c|c|c|c|c|c|c|c|c|c|c|c|}
\hline \multirow[b]{2}{*}{$\begin{array}{l}\text { No. } \\
\text { (figs. } \\
2-5)\end{array}$} & \multirow[b]{2}{*}{ Citation } & \multicolumn{9}{|c|}{ Type of study } & \multicolumn{6}{|c|}{ Ecoregion } \\
\hline & & $\begin{array}{l}\text { Verte- } \\
\text { brates }\end{array}$ & $\begin{array}{l}\text { Inverte- } \\
\text { brates }\end{array}$ & Plants & $\begin{array}{c}\text { Troglo- } \\
\text { bites }\end{array}$ & $\begin{array}{l}\text { Non- } \\
\text { indig- } \\
\text { enous }\end{array}$ & $\begin{array}{c}\text { Habi- } \\
\text { tat }\end{array}$ & $\begin{array}{l}\text { Edwards } \\
\text { aquifer }\end{array}$ & $\begin{array}{l}\text { Species } \\
\text { of con- } \\
\text { cern }\end{array}$ & $\begin{array}{c}\text { Water } \\
\text { chem- } \\
\text { istry }\end{array}$ & $\begin{array}{l}\text { Edwards } \\
\text { Plateau }\end{array}$ & $\begin{array}{l}\text { Texas } \\
\text { Black- } \\
\text { land } \\
\text { Prairies }\end{array}$ & $\begin{array}{l}\text { East } \\
\text { Central } \\
\text { Texas } \\
\text { Plains }\end{array}$ & $\begin{array}{l}\text { Western } \\
\text { Gulf } \\
\text { Coastal } \\
\text { Plain }\end{array}$ & $\begin{array}{l}\text { South- } \\
\text { ern } \\
\text { Texas } \\
\text { Plains }\end{array}$ & Subject \\
\hline 57 & Short, 1982 & $\mathrm{X}$ & $\mathrm{X}$ & & & & & & & & $\mathrm{X}$ & & & & & $\begin{array}{l}\text { Diel changes in water temperature, dissolved } \\
\text { oxygen, conductivity, invertebrate drift, } \\
\text { invertebrate food habits, and fish food } \\
\text { habits in Guadalupe River. }\end{array}$ \\
\hline 58 & $\begin{array}{l}\text { Short and Smith, } \\
1989\end{array}$ & & $\mathrm{X}$ & & & & & & & & $\mathrm{X}$ & & & & & $\begin{array}{l}\text { Seasonal comparison of processing of } \\
\text { hackberry leaves indicating temperature as } \\
\text { primary factor influencing processing rate } \\
\text { in Honey Creek. }\end{array}$ \\
\hline 59 & Solanik, 1996 & & $\mathrm{X}$ & & & & & & & & $\mathrm{X}$ & $\mathrm{X}$ & & & & $\begin{array}{l}\text { Effect of season and intermittency on } \\
\text { patterns of longitudinal variation in } \\
\text { macroinvertebrate taxonomic and } \\
\text { functional feeding group composition of } \\
\text { Cibolo Creek. }\end{array}$ \\
\hline 60 & Stanley, 1986 & & $\mathrm{X}$ & & & & & & & & $\mathrm{X}$ & & $\mathrm{X}$ & & & $\begin{array}{l}\text { Distribution, life histories, and production of } \\
\text { mayflies in Guadalupe River Basin. }\end{array}$ \\
\hline 61 & $\begin{array}{l}\text { Stanley and Short, } \\
1988\end{array}$ & & $\mathrm{X}$ & & & & & & & & $\mathrm{X}$ & & & & & $\begin{array}{l}\text { Determination of efficacy of thermal } \\
\text { equilibrium hypothesis with warmwater } \\
\text { insects in Blanco River and Honey Creek } \\
\text { (Guadalupe River Basin). }\end{array}$ \\
\hline 62 & Staton, 1992 & & & $\mathrm{X}$ & & $\mathrm{X}$ & & & & & & & & & & $\begin{array}{l}\text { Determination of recent negative impacts in } \\
\text { aquatic macrophyte community in San } \\
\text { Marcos River and projection of effect on } \\
\text { aquatic flora. }\end{array}$ \\
\hline 63 & $\begin{array}{l}\text { Stock and } \\
\quad \text { Longley, } 1981\end{array}$ & & $\mathrm{X}$ & & $\mathrm{X}$ & & & $\mathrm{X}$ & & & $\mathrm{X}$ & & & & & $\begin{array}{l}\text { Distribution of only known North American } \\
\text { thermosbaenacean, Monodella texana } \\
\text { Maguire. }\end{array}$ \\
\hline 64 & Strenth, 1976 & & $\mathrm{X}$ & & $\mathrm{X}$ & & & $\mathrm{X}$ & & & $\mathrm{X}$ & & & & & $\begin{array}{l}\text { Troglobitic shrimp from Ezell's Cave in San } \\
\text { Marcos. }\end{array}$ \\
\hline 65 & $\begin{array}{l}\text { Strenth and } \\
\quad \text { Longley, } 1990\end{array}$ & & $\mathrm{X}$ & & $\mathrm{X}$ & & & $\mathrm{X}$ & & & $\mathrm{X}$ & & & & & $\begin{array}{l}\text { Determination of absence of seasonal period } \\
\text { of reproduction in subterranean shrimp, } \\
\text { Palaemonetes antrorum, from Central } \\
\text { Texas. }\end{array}$ \\
\hline 66 & $\begin{array}{l}\text { Taylor, 1995/ } \\
\text { Taylor and } \\
\text { Ferreira, } 1995\end{array}$ & & $\mathrm{X}$ & $\mathrm{X}$ & & & $\mathrm{X}$ & & & $\mathrm{X}$ & & $\mathrm{X}$ & & & & $\begin{array}{l}\text { Biological survey of benthic } \\
\text { macroinvertebrates, periphyton, and } \\
\text { phytoplankton, community } \\
\text { characteristics, and associated water } \\
\text { quality for lower Olmos Creek and upper } \\
\text { San Antonio River. }\end{array}$ \\
\hline
\end{tabular}


Table 1. Literature citations for biological surveys and field studies in the South-Central Texas study unit, Texas-Continued

\begin{tabular}{|c|c|c|c|c|c|c|c|c|c|c|c|c|c|c|c|c|}
\hline \multirow[b]{2}{*}{$\begin{array}{l}\text { No. } \\
\text { (figs. } \\
2-5)\end{array}$} & \multirow[b]{2}{*}{ Citation } & \multicolumn{9}{|c|}{ Type of study } & \multicolumn{6}{|c|}{ Ecoregion } \\
\hline & & $\begin{array}{l}\text { Verte- } \\
\text { brates }\end{array}$ & $\begin{array}{l}\text { Inverte- } \\
\text { brates }\end{array}$ & Plants & $\begin{array}{c}\text { Troglo- } \\
\text { bites }\end{array}$ & $\begin{array}{l}\text { Non- } \\
\text { indig- } \\
\text { enous }\end{array}$ & $\begin{array}{c}\text { Habi- } \\
\text { tat }\end{array}$ & $\begin{array}{l}\text { Edwards } \\
\text { aquifer }\end{array}$ & $\begin{array}{l}\text { Species } \\
\text { of con- } \\
\text { cern }\end{array}$ & $\begin{array}{c}\text { Water } \\
\text { chem- } \\
\text { istry }\end{array}$ & $\begin{array}{l}\text { Edwards } \\
\text { Plateau }\end{array}$ & $\begin{array}{l}\text { Texas } \\
\text { Black- } \\
\text { land } \\
\text { Prairies }\end{array}$ & $\begin{array}{l}\text { East } \\
\text { Central } \\
\text { Texas } \\
\text { Plains }\end{array}$ & $\begin{array}{l}\text { Western } \\
\text { Gulf } \\
\text { Coastal } \\
\text { Plain }\end{array}$ & $\begin{array}{l}\text { South- } \\
\text { ern } \\
\text { Texas } \\
\text { Plains }\end{array}$ & Subject \\
\hline 67 & $\begin{array}{l}\text { Terre and } \\
\quad \text { Magnelia, } 1996\end{array}$ & $X$ & & & & $X$ & & & & & $\mathrm{X}$ & $X$ & & & & $\begin{array}{l}\text { Sport fish stocking histories and sampling } \\
\text { results in Guadalupe River. }\end{array}$ \\
\hline 68 & $\begin{array}{l}\text { Terre and } \\
\quad \text { Magnelia, } 1997\end{array}$ & $\mathrm{X}$ & & & & & & & & & $\mathrm{X}$ & & & & & $\begin{array}{l}\text { Physical and historical data, habitat survey, } \\
\text { stocking history, location of sites, water } \\
\text { levels, species information, and fisheries } \\
\text { management plan for Canyon Reservoir. }\end{array}$ \\
\hline 69 & $\begin{array}{l}\text { Texas System of } \\
\text { Natural } \\
\text { Laboratories, } \\
\text { Inc., } 1994\end{array}$ & $\mathrm{X}$ & & & & & & & & & & & & & & $\begin{array}{l}\text { Taxonomic and distributional inventory of } \\
\text { freshwater and marine fishes of Texas } \\
\text { with bibliography. }\end{array}$ \\
\hline 70 & Tiemann, 1992 & & $\mathrm{X}$ & & & & & & & & $\mathrm{X}$ & $\mathrm{X}$ & & & & $\begin{array}{l}\text { Caddisfly diversity and life histories in } \\
\text { streams on Edwards Plateau. }\end{array}$ \\
\hline 71 & Tomme, 1974 & & $\mathrm{X}$ & & & & & & & $\mathrm{X}$ & & $\mathrm{X}$ & & & & $\begin{array}{l}\text { Collection of physical, chemical, and } \\
\text { biological data for Cibolo Creek. }\end{array}$ \\
\hline 72 & Trebatoski, 1991 & $\mathrm{X}$ & & & & & $\mathrm{X}$ & & & & & & & $\mathrm{X}$ & & $\begin{array}{l}\text { Investigation of potential impact of } \\
\text { municipal-wastewater discharge into } \\
\text { Guadalupe River. }\end{array}$ \\
\hline 73 & Twidwell, 1975 & & $\mathrm{X}$ & & & & & & & $\mathrm{X}$ & & & $\mathrm{X}$ & $\mathrm{X}$ & & $\begin{array}{l}\text { Collection of physical, chemical, and } \\
\text { biological data for San Antonio River. }\end{array}$ \\
\hline 74 & Twidwell, 1976 & & $\mathrm{X}$ & & & & & & & $\mathrm{X}$ & & $\mathrm{X}$ & & & & $\begin{array}{l}\text { Collection of physical, chemical, and } \\
\text { biological data for Medina River. }\end{array}$ \\
\hline 75 & Twidwell, 1984 & $\mathrm{X}$ & $X$ & & & & & & & $\mathrm{X}$ & & & $\mathrm{X}$ & $X$ & & $\begin{array}{l}\text { Two surveys, } 1983 \text { - collection of physical, } \\
\text { chemical, and biological data (fish and } \\
\text { benthic macroinvertebrates) for San } \\
\text { Antonio River. }\end{array}$ \\
\hline 76 & Twidwell, 1987 & & $\mathrm{X}$ & & & & & & & $\mathrm{X}$ & $\mathrm{X}$ & & & & & $\begin{array}{l}\text { Hydrology, field measurements, water } \\
\text { chemistry, and benthic macroinvertebrates } \\
\text { for Guadalupe River. }\end{array}$ \\
\hline 77 & $\begin{array}{l}\text { Twidwell and } \\
\text { Davis, } 1987\end{array}$ & & $\mathrm{X}$ & & & & & & & $\mathrm{X}$ & & $\mathrm{X}$ & $\mathrm{X}$ & $\mathrm{X}$ & & Four seasonal surveys of San Antonio River. \\
\hline 78 & $\begin{array}{l}\text { U.S. Fish and } \\
\text { Wildlife } \\
\text { Service, } 1995\end{array}$ & $\mathrm{X}$ & $\mathrm{X}$ & $\mathrm{X}$ & $\mathrm{X}$ & & $\mathrm{X}$ & $\mathrm{X}$ & $\mathrm{X}$ & & $\mathrm{X}$ & & & & & $\begin{array}{l}\text { Development of recovery plan for aquatic } \\
\text { endangered species in San Marcos and } \\
\text { Comal Springs. }\end{array}$ \\
\hline
\end{tabular}


Table 2. Fish collected in streams of the South-Central Texas study unit, Texas

[From Texas System of Natural Laboratories, Inc. (1994). River basin: G, Guadalupe; SA, San Antonio; N, Nueces; SN, San Antonio-Nueces Coastal; NR, Nueces-Rio Grande Coastal]

\begin{tabular}{|c|c|c|}
\hline $\begin{array}{l}\text { Order } \\
\text { Family } \\
\quad \text { Common name }\end{array}$ & Genus & River basin \\
\hline \multicolumn{3}{|l|}{ Lepisosteiformes } \\
\hline \multicolumn{3}{|l|}{ Lepisosteidae (gars) } \\
\hline Spotted gar & Lepisosteus oculatus & $\mathrm{G}, \mathrm{SA}, \mathrm{N}, \mathrm{SN}, \mathrm{NR}$ \\
\hline Longnose gar & Lepisosteus osseus & $\mathrm{G}, \mathrm{SA}, \mathrm{N}, \mathrm{SN}, \mathrm{NR}$ \\
\hline Alligator gar & Lepisosteus spatula & $\mathrm{G}, \mathrm{SA}, \mathrm{N}, \mathrm{SN}, \mathrm{NR}$ \\
\hline \multicolumn{3}{|l|}{ Anguilliformes } \\
\hline \multicolumn{3}{|l|}{ Anguillidae (freshwater eels) } \\
\hline American eel & Anguilla rostrata & $\mathrm{G}, \mathrm{SA}, \mathrm{N}, \mathrm{SN}, \mathrm{NR}$ \\
\hline \multicolumn{3}{|l|}{ Clupeiformes } \\
\hline \multicolumn{3}{|l|}{ Clupeidae (herrings) } \\
\hline Skipjack herring & Alosa chrysochloris & $\mathrm{G}, \mathrm{SA}$ \\
\hline American shad & Alosa sapidissima & $\mathrm{G}, \mathrm{SA}$ \\
\hline Gizzard shad & Dorosoma cepedianum & $\mathrm{G}, \mathrm{SA}, \mathrm{N}, \mathrm{SN}, \mathrm{NR}$ \\
\hline Threadfin shad & Dorosoma petenense & $\mathrm{G}, \mathrm{SA}, \mathrm{N}, \mathrm{SN}, \mathrm{NR}$ \\
\hline \multicolumn{3}{|l|}{ Engraulidae (anchovies) } \\
\hline Bay anchovy & Anchoa mitchilli & $\mathrm{N}, \mathrm{SN}, \mathrm{NR}$ \\
\hline \multicolumn{3}{|l|}{ Cypriniformes } \\
\hline \multicolumn{3}{|l|}{ Cyprinidae (carps and minnows) } \\
\hline Central stoneroller & Campostoma anomalum & $\mathrm{G}, \mathrm{SA}, \mathrm{N}$ \\
\hline Mexican stoneroller & Campostoma ornatum & $\mathrm{N}$ \\
\hline Goldfish & Carassius auratus & $\mathrm{G}, \mathrm{N}$ \\
\hline Plateau shiner & Cyprinella lepida & $\mathrm{G}, \mathrm{N}$ \\
\hline Red shiner & Cyprinella lutrensis & $\mathrm{G}, \mathrm{SA}, \mathrm{N}, \mathrm{SN}$ \\
\hline Blacktail shiner & Cyprinella venusta & $\mathrm{G}, \mathrm{SA}, \mathrm{N}$ \\
\hline Common carp & Cyprinus carpio & $\mathrm{G}, \mathrm{SA}, \mathrm{N}, \mathrm{NR}$ \\
\hline Roundnose minnow & Dionda episcopa & $\mathrm{G}, \mathrm{N}$ \\
\hline Nueces roundnose minnow & Dionda serena & SA, N \\
\hline Plains minnow & Hybognathus placitus & $\mathrm{G}$ \\
\hline Speckled chub & Macrhybopsis aestivalis & $\mathrm{G}, \mathrm{SA}, \mathrm{N}$ \\
\hline Golden shiner & Notemigonus crysoleucas & $\mathrm{G}, \mathrm{SA}, \mathrm{N}$ \\
\hline Texas shiner & Notropis amabilis & $\mathrm{G}, \mathrm{SA}, \mathrm{N}$ \\
\hline Pallid shiner & Notropis amnis & $\mathrm{G}, \mathrm{SA}$ \\
\hline Blackspot shiner & Notropis atrocaudalis & $\mathrm{G}, \mathrm{SA}$ \\
\hline River shiner & Notropis blennius & SA \\
\hline Ghost shiner & Notropis buchanani & $\mathrm{G}, \mathrm{SA}, \mathrm{N}$ \\
\hline Ironcolor shiner & Notropis chalybaeus & G \\
\hline Sand shiner & Notropis stramineus & $\mathrm{G}, \mathrm{SA}, \mathrm{N}$ \\
\hline Weed shiner & Notropis texanus & $\mathrm{G}, \mathrm{SA}, \mathrm{N}$ \\
\hline Mimic shiner & Notropis volucellus & $\mathrm{G}, \mathrm{SA}, \mathrm{N}$ \\
\hline Pugnose minnow & Opsopoeodus emiliae & $\mathrm{G}, \mathrm{SA}, \mathrm{N}$ \\
\hline Suckermouth minnow & Phenacobius mirabilis & $\mathrm{N}$ \\
\hline Bluntnose minnow & Pimephales notatus & $\mathrm{N}$ \\
\hline Fathead minnow & Pimephales promelas & $\mathrm{G}, \mathrm{SA}$ \\
\hline
\end{tabular}


Table 2. Fish collected in streams of the South-Central Texas study unit, Texas-Continued

\begin{tabular}{|c|c|c|}
\hline $\begin{array}{l}\text { Order } \\
\qquad \text { Family } \\
\quad \text { Common name }\end{array}$ & Genus & River basin \\
\hline \multicolumn{3}{|l|}{ Cypriniformes-Continued } \\
\hline \multicolumn{3}{|c|}{ Cyprinidae (carps and minnows) — Continued } \\
\hline Bullhead minnow & Pimephales vigilax & $\mathrm{G}, \mathrm{SA}, \mathrm{N}$ \\
\hline Tench & Tinca tinca & $\mathrm{G}$ \\
\hline \multicolumn{3}{|l|}{ Catostomidae (suckers) } \\
\hline River carpsucker & Carpiodes carpio & $\mathrm{G}, \mathrm{SA}, \mathrm{N}, \mathrm{SN}, \mathrm{NR}$ \\
\hline Creek chubsucker & Erimyzon oblongus & $\mathrm{G}$ \\
\hline Lake chubsucker & Erimyzon sucetta & G \\
\hline Smallmouth buffalo & Ictiobus bubalus & $\mathrm{G}, \mathrm{SA}, \mathrm{N}, \mathrm{SN}, \mathrm{NR}$ \\
\hline Spotted sucker & Minytrema melanops & $\mathrm{G}$ \\
\hline Gray redhorse & Moxostoma congestum & $\mathrm{G}, \mathrm{SA}, \mathrm{N}$ \\
\hline \multicolumn{3}{|l|}{ Characiformes } \\
\hline \multicolumn{3}{|l|}{ Characidae (characins) } \\
\hline Mexican tetra & Astyanax mexicanus & $\mathrm{G}, \mathrm{SA}, \mathrm{N}, \mathrm{NR}$ \\
\hline \multicolumn{3}{|l|}{ Siluriformes } \\
\hline \multicolumn{3}{|c|}{ Ictaluridae (bullhead catfishes) } \\
\hline Black bullhead & Ameiurus melas & $\mathrm{G}, \mathrm{SA}, \mathrm{N}, \mathrm{SN}, \mathrm{NR}$ \\
\hline Yellow bullhead & Ameiurus natalis & $\mathrm{G}, \mathrm{SA}, \mathrm{N}, \mathrm{SN}, \mathrm{NR}$ \\
\hline Brown bullhead & Ameiurus nebulosus & $\mathrm{G}, \mathrm{SA}, \mathrm{N}, \mathrm{NR}$ \\
\hline Blue catfish & Ictalurus furcatus & $\mathrm{G}, \mathrm{SA}, \mathrm{N}, \mathrm{SN}, \mathrm{NR}$ \\
\hline Headwater catfish & Ictalurus lupus & $\mathrm{SA}, \mathrm{N}$ \\
\hline Channel catfish & Ictalurus punctatus & $\mathrm{G}, \mathrm{SA}, \mathrm{N}, \mathrm{SN}, \mathrm{NR}$ \\
\hline Tadpole madtom & Noturus gyrinus & $\mathrm{SA}, \mathrm{N}, \mathrm{SN}$ \\
\hline Flathead catfish & Pylodictis olivaris & $\mathrm{G}, \mathrm{SA}, \mathrm{N}$ \\
\hline Widemouth blindcat & Satan eurystomus & $\mathrm{SA}$ \\
\hline Toothless blindcat & Trogloglanis pattersoni & SA \\
\hline \multicolumn{3}{|l|}{ Ariidae (sea catfishes) } \\
\hline Hardhead catfish & Arius felis & G, SN, NR \\
\hline Gafftopsail catfish & Bagre marinus & NR \\
\hline \multicolumn{3}{|c|}{ Loricariidae (suckermouth catfishes) } \\
\hline Suckermouth catfish & Hypostomus plecostomus & SA \\
\hline \multicolumn{3}{|c|}{ Atheriniformes (Cyprinodontiformes) } \\
\hline \multicolumn{3}{|c|}{ Cyprinodontidae (killifishes) } \\
\hline Diamond killifish & Adinia xenica & $\mathrm{N}, \mathrm{NR}$ \\
\hline Sheepshead minnow & Cyprinodon variegatus & G, SA, SN, NR \\
\hline Gulf killifish & Fundulus grandis & $\mathrm{G}, \mathrm{N}, \mathrm{SN}, \mathrm{NR}$ \\
\hline Blackstripe topminnow & Fundulus notatus & $\mathrm{G}, \mathrm{SA}$ \\
\hline Bayou killifish & Fundulus pulvereus & $\mathrm{G}, \mathrm{N}, \mathrm{SN}, \mathrm{NR}$ \\
\hline Longnose killifish & Fundulus similis & SN, NR \\
\hline Plains killifish & Fundulus zebrinus & $\mathrm{N}$ \\
\hline Rainwater killifish & Lucania parva & $\mathrm{G}, \mathrm{SA}, \mathrm{N}, \mathrm{SN}, \mathrm{NR}$ \\
\hline \multicolumn{3}{|l|}{ Poeciliidae (livebearers) } \\
\hline Pike killifish & Belonesox belizanus & SA \\
\hline Western mosquitofish & Gambusia affinis & $\mathrm{G}, \mathrm{SA}, \mathrm{N}, \mathrm{SN}, \mathrm{NR}$ \\
\hline Largespring gambusia & Gambusia geiseri & $\mathrm{G}$ \\
\hline San Marcos gambusia & Gambusia georgei & $\mathrm{G}, \mathrm{N}$ \\
\hline
\end{tabular}


Table 2. Fish collected in streams of the South-Central Texas study unit, Texas-Continued

\begin{tabular}{|c|c|c|}
\hline $\begin{array}{l}\text { Order } \\
\text { Family } \\
\quad \text { Common name }\end{array}$ & Genus & River basin \\
\hline \multicolumn{3}{|c|}{ Atheriniformes (Cyprinodontiformes)—Continued } \\
\hline \multicolumn{3}{|c|}{ Poeciliidae (livebearers)—Continued } \\
\hline Amazon molly & Poecilia formosa & $\mathrm{G}, \mathrm{SA}, \mathrm{N}$ \\
\hline Sailfin molly & Poecilia latipinna & $\mathrm{G}, \mathrm{SA}, \mathrm{N}, \mathrm{SN}, \mathrm{NR}$ \\
\hline \multicolumn{3}{|l|}{ Atherinidae (silversides) } \\
\hline Rough silverside & Membras martinica & SN \\
\hline Inland silverside & Menidia beryllina & $\mathrm{G}, \mathrm{SN}, \mathrm{NR}$ \\
\hline Atlantic silverside & Menidia menidia & SN \\
\hline \multicolumn{3}{|l|}{ Zeiformes } \\
\hline \multicolumn{3}{|l|}{ Syngnathidae (pipefishes) } \\
\hline Gulf pipefish & Syngnathus scovelli & SN, NR \\
\hline \multicolumn{3}{|l|}{ Perciformes } \\
\hline \multicolumn{3}{|l|}{ Centropomidae (snooks) } \\
\hline Common snook & Centropomus undecimalis & $\mathrm{N}$ \\
\hline \multicolumn{3}{|c|}{ Percichthyidae (temperate basses) } \\
\hline White bass & Morone chrysops & $\mathrm{G}, \mathrm{SA}$ \\
\hline \multicolumn{3}{|l|}{ Centrarchidae (sunfishes) } \\
\hline Rock bass & Ambloplites rupestris & $\mathrm{G}$ \\
\hline Flier & Centrarchus macropterus & SA \\
\hline Banded pygmy sunfish & Elassoma zonatum & SA \\
\hline Redbreast sunfish & Lepomis auritus & $\mathrm{G}, \mathrm{SA}, \mathrm{N}$ \\
\hline Green sunfish & Lepomis cyanellus & $\mathrm{G}, \mathrm{SA}, \mathrm{N}, \mathrm{SN}, \mathrm{NR}$ \\
\hline Warmouth & Lepomis gulosus & $\mathrm{G}, \mathrm{SA}, \mathrm{N}, \mathrm{SN}, \mathrm{NR}$ \\
\hline Bluegill & Lepomis macrochirus & $\mathrm{G}, \mathrm{SA}, \mathrm{N}, \mathrm{SN}, \mathrm{NR}$ \\
\hline Longear sunfish & Lepomis megalotis & $\mathrm{G}, \mathrm{SA}, \mathrm{N}, \mathrm{SN}, \mathrm{NR}$ \\
\hline Redear sunfish & Lepomis microlophus & $\mathrm{G}, \mathrm{SA}, \mathrm{N}, \mathrm{SN}, \mathrm{NR}$ \\
\hline Spotted sunfish & Lepomis punctatus & $\mathrm{G}, \mathrm{SA}, \mathrm{N}$ \\
\hline Smallmouth bass & Micropterus dolomieu & $\mathrm{G}$ \\
\hline Spotted bass & Micropterus punctulatus & $\mathrm{G}, \mathrm{SA}$ \\
\hline Largemouth bass & Micropterus salmoides & $\mathrm{G}, \mathrm{SA}, \mathrm{N}, \mathrm{SN}, \mathrm{NR}$ \\
\hline Guadalupe bass & Micropterus treculi & $\mathrm{G}, \mathrm{SA}$ \\
\hline White crappie & Pomoxis annularis & $\mathrm{G}, \mathrm{SA}, \mathrm{N}, \mathrm{SN}, \mathrm{NR}$ \\
\hline Black crappie & Pomoxis nigromaculatus & $\mathrm{G}, \mathrm{SA}, \mathrm{N}$ \\
\hline \multicolumn{3}{|c|}{ Salmonidae (salmon and trout) } \\
\hline Rainbow trout & Oncorhynchus mykiss & G \\
\hline Brown trout & Salmo trutta & G \\
\hline Brook trout & Salvelinus fontinalis & G \\
\hline \multicolumn{3}{|l|}{ Percidae (perches) } \\
\hline Bluntnose darter & Etheostoma chlorosomum & $\mathrm{G}, \mathrm{SA}$ \\
\hline Fountain darter & Etheostoma fonticola & G \\
\hline Swamp darter & Etheostoma fusiforme & $\mathrm{N}$ \\
\hline Slough darter & Etheostoma gracile & $\mathrm{G}, \mathrm{SA}, \mathrm{N}$ \\
\hline Greenthroat darter & Etheostoma lepidum & $\mathrm{G}, \mathrm{SA}, \mathrm{N}$ \\
\hline Orangethroat darter & Etheostoma spectabile & $\mathrm{G}, \mathrm{SA}, \mathrm{N}$ \\
\hline Logperch & Percina caprodes & $\mathrm{G}, \mathrm{SA}$ \\
\hline Texas logperch & Percina carbonaria & $\mathrm{G}, \mathrm{SA}$ \\
\hline
\end{tabular}


Table 2. Fish collected in streams of the South-Central Texas study unit, Texas-Continued

\begin{tabular}{|c|c|c|}
\hline $\begin{array}{l}\text { Order } \\
\qquad \text { Family } \\
\quad \text { Common name }\end{array}$ & Genus & River basin \\
\hline \multicolumn{3}{|l|}{ Perciformes-Continued } \\
\hline \multicolumn{3}{|c|}{ Percidae (perches)—Continued } \\
\hline Bigscale logperch & Percina macrolepida & G \\
\hline Dusky darter & Percina sciera & G \\
\hline River darter & Percina shumardi & $\mathrm{G}, \mathrm{SA}$ \\
\hline \multicolumn{3}{|l|}{ Sparidae (porgies) } \\
\hline Sheepshead & Archosargus probatocephalus & $\mathrm{N}$ \\
\hline Pinfish & Lagodon rhomboides & SN \\
\hline \multicolumn{3}{|l|}{ Sciaenidae (drums) } \\
\hline Freshwater drum & Aplodinotus grunniens & $\mathrm{N}, \mathrm{NR}$ \\
\hline Silver perch & Bairdiella chrysoura & SN, NR \\
\hline Sand seatrout & Cynoscion arenarius & $\mathrm{N}$ \\
\hline Spotted seatrout & Cynoscion nebulosus & $\mathrm{G}, \mathrm{N}$ \\
\hline Silver seatrout & Cynoscion nothus & $\mathrm{N}$ \\
\hline Spot & Leiostomus xanthurus & G \\
\hline Atlantic croaker & Micropogonias undulatus & $\mathrm{N}, \mathrm{SN}, \mathrm{NR}$ \\
\hline Black drum & Pogonias cromis & $\mathrm{G}, \mathrm{N}, \mathrm{SN}, \mathrm{NR}$ \\
\hline Red drum & Sciaenops ocellatus & $\mathrm{G}$ \\
\hline \multicolumn{3}{|l|}{ Cichlidae (cichlids) } \\
\hline Rio Grande cichlid & Cichlasoma cyanoguttatum & $\mathrm{G}, \mathrm{SA}, \mathrm{N}, \mathrm{SN}, \mathrm{NR}$ \\
\hline Blue tilapia & Tilapia aurea & $\mathrm{G}, \mathrm{SA}$ \\
\hline Mozambique tilapia & Tilapia mossambica & $\mathrm{G}, \mathrm{SA}$ \\
\hline Redbelly tilapia & Tilapia zilli & SA \\
\hline \multicolumn{3}{|l|}{ Mugilidae (mullets) } \\
\hline Mountain mullet & Agonostomus monticola & $\mathrm{G}, \mathrm{SA}, \mathrm{N}$ \\
\hline Striped mullet & Mugil cephalus & $\mathrm{G}, \mathrm{SA}, \mathrm{N}, \mathrm{SN}, \mathrm{NR}$ \\
\hline White mullet & Mugil curema & $\mathrm{G}, \mathrm{SA}, \mathrm{SN}$ \\
\hline \multicolumn{3}{|l|}{ Eleotridae (sleepers) } \\
\hline Fat sleeper & Dormitator maculatus & SN \\
\hline Spinycheek sleeper & Eleotris pisonis & $\mathrm{N}$ \\
\hline Bigmouth sleeper & Gobiomorus dormitor & SN \\
\hline \multicolumn{3}{|l|}{ Gobiidae (gobies) } \\
\hline Freshwater goby & Gobionellus shufeldti & $\mathrm{G}$ \\
\hline Naked goby & Gobiosoma bosc & $\mathrm{G}, \mathrm{N}, \mathrm{SN}$ \\
\hline Code goby & Gobiosoma robustum & G, NR \\
\hline Clown goby & Microgobius gulosus & $\mathrm{G}$ \\
\hline Green goby & Microgobius thalassinus & $\mathrm{G}$ \\
\hline \multicolumn{3}{|l|}{ Pleuronectiformes } \\
\hline \multicolumn{3}{|l|}{ Bothidae (lefteye flounders) } \\
\hline Southern flounder & Paralichthys lethostigma & $\mathrm{G}, \mathrm{N}, \mathrm{SN}, \mathrm{NR}$ \\
\hline \multicolumn{3}{|l|}{ Soleidae (soles) } \\
\hline Lined sole & Achirus lineatus & NR \\
\hline Blackcheek tonguefish & Symphurus plagiusa & NR \\
\hline Hogchoker & Trinectes maculatus & $\mathrm{N}, \mathrm{SN}$ \\
\hline \multicolumn{3}{|l|}{ Tetraodontiformes } \\
\hline \multicolumn{3}{|l|}{ Tetraodontidae (puffers) } \\
\hline Least puffer & Sphoeroides parvus & $\mathrm{N}, \mathrm{SN}, \mathrm{NR}$ \\
\hline
\end{tabular}


Table 3. Aquatic invertebrates collected in streams of the South-Central Texas study unit, Texas

[From Bayer and others (1992); Davis (1982); Richerson (1982); Taylor (1995); and Taylor and Ferreira (1995). River basin: SA, San Antonio; G, Guadalupe; N, Nueces. Ecoregion: EP, Edwards Plateau; STP, Southern Texas Plains; TBP, Texas Blackland Prairies; ECTP, East Central Texas Plains. N/D, not determined]

\begin{tabular}{|c|c|c|c|}
\hline $\begin{array}{l}\text { Class } \\
\text { Order } \\
\quad \text { Family }\end{array}$ & Genus & $\begin{array}{l}\text { River } \\
\text { basin }\end{array}$ & Ecoregion \\
\hline \multicolumn{4}{|l|}{ Arachnoidea } \\
\hline \multicolumn{4}{|l|}{ Hydracarina } \\
\hline Limnocharidae & Limnochares sp. & SA & $\mathrm{EP}$ \\
\hline \multicolumn{4}{|l|}{ Crustacea } \\
\hline \multicolumn{4}{|l|}{ Amphipoda } \\
\hline Talitridae & Hyalella azteca & $\mathrm{G}$ & $\mathrm{EP}$ \\
\hline \multicolumn{4}{|l|}{ Ostracoda (Podocopa) } \\
\hline \multirow[t]{3}{*}{ Cyprididae } & Chlamydotheca arcuata & $\mathrm{G}$ & $\mathrm{EP}$ \\
\hline & Herpetocypris $\mathrm{nr}$. reptans & SA & EP \\
\hline & Stenocypris nr. malcolmsoni & G & EP \\
\hline Darwinulidae & Darwinula stevensoni & $\mathrm{N}$ & STP \\
\hline Limnocytheridae & Limnocythere sp. & $\mathrm{N}$ & STP \\
\hline \multicolumn{4}{|l|}{ Gastropoda } \\
\hline \multicolumn{4}{|c|}{ Limnophila (Pulmonates) } \\
\hline \multirow[t]{2}{*}{ Ancylidae } & Ferrissia rivularis & $\mathrm{G}$ & $\mathrm{EP}$ \\
\hline & Hebetancylus excentricus & SA & TBP \\
\hline \multirow[t]{2}{*}{ Lymnaeidae } & Fossaria parva & $\mathrm{G}, \mathrm{N}$ & EP, STP \\
\hline & Pseudosuccinea columella & $\mathrm{N}$ & STP \\
\hline \multirow[t]{2}{*}{ Physidae } & Physa sp. & SA & $\mathrm{TBP}$ \\
\hline & Physella virgata & $\mathrm{G}, \mathrm{N}$ & EP, STP \\
\hline \multirow[t]{4}{*}{ Planorbidae } & Biomphalaria obstructus & G & EP \\
\hline & Gyraulus parvus & $\mathrm{N}$ & STP \\
\hline & Gyraulus sp. & SA & TBP \\
\hline & Planorbella trivolvis & $\mathrm{N}$ & STP \\
\hline \multicolumn{4}{|l|}{ Mesogastropoda } \\
\hline \multirow[t]{2}{*}{ Hydrobiidae } & Cincinnatia cincinnatiensis & G & EP, TBP \\
\hline & Pyrgophorus spinosus & $\mathrm{N}$ & STP \\
\hline \multicolumn{4}{|l|}{ Hirudinea } \\
\hline \multicolumn{4}{|l|}{ Rhynchobdellida } \\
\hline \multirow[t]{3}{*}{ Glossiphoniidae } & Glossiphonia heteroclita & SA & TBP \\
\hline & Helobdella fusca & SA & TBP \\
\hline & Helobdella stagnalis & G & EP \\
\hline \multicolumn{4}{|l|}{ Insecta (Hexopoda) } \\
\hline \multicolumn{4}{|l|}{ Coleoptera } \\
\hline \multirow[t]{3}{*}{ Dryopidae } & Helichus suturalis & SA & EP \\
\hline & Haideoporus texanus & G & $\mathrm{EP}$ \\
\hline & Hydroporus sp. & $\mathrm{N}$ & STP \\
\hline \multirow[t]{3}{*}{ Elmidae } & Elsianus texanus & G & EP, TBP \\
\hline & Hexacylloepus ferrugineus & $\mathrm{G}, \mathrm{SA}$ & EP, TBP \\
\hline & Microcylloepus sp. & $\mathrm{G}, \mathrm{SA}, \mathrm{N}$ & EP, TBP, STP \\
\hline
\end{tabular}


Table 3. Aquatic invertebrates collected in streams of the South-Central Texas study unit, Texas-Continued

\begin{tabular}{|c|c|c|c|}
\hline $\begin{array}{l}\text { Class } \\
\text { Order } \\
\quad \text { Family }\end{array}$ & Genus & $\begin{array}{l}\text { River } \\
\text { basin }\end{array}$ & Ecoregion \\
\hline \multicolumn{4}{|c|}{ Insecta (Hexopoda)—Continued } \\
\hline \multicolumn{4}{|c|}{ Coleoptera-Continued } \\
\hline \multirow[t]{5}{*}{ Elmidae-Continued } & Microcylloepus pusillus & $\mathrm{G}, \mathrm{SA}, \mathrm{N}$ & EP, TBP, STP \\
\hline & Neoelmis caesa & $\mathrm{G}, \mathrm{SA}$ & EP, TBP \\
\hline & Stenelmis occidentalis & $\mathrm{G}, \mathrm{SA}$ & EP TBP \\
\hline & Stenelmis sexlineata & $\mathrm{G}, \mathrm{SA}$ & $\mathrm{TBP}$ \\
\hline & Stenelmis sp. & $\mathrm{G}, \mathrm{SA}$ & EP, TBP, STP \\
\hline Gyrinidae & Dineutus sp. & $\mathrm{N}$ & STP \\
\hline Hydrophilidae & Enochrus sp. & G & EP \\
\hline Limnichidae & Lutrochus luteus & SA & $\mathrm{EP}$ \\
\hline \multirow[t]{2}{*}{ Scirtidae } & Cyphon sp. & $\mathrm{N}$ & STP \\
\hline & Labrundinia sp. & SA & TBP \\
\hline \multicolumn{4}{|l|}{ Diptera } \\
\hline \multirow[t]{3}{*}{ Ceratopogonidae } & Bezzia sp. & SA & $\mathrm{EP}$ \\
\hline & Palpomyia tibialis & $\mathrm{G}, \mathrm{SA}$ & $\mathrm{EP}$ \\
\hline & Probezzia sp. & $\mathrm{G}, \mathrm{SA}$ & EP, TBP \\
\hline \multirow[t]{27}{*}{ Chironomidae } & Cardiocladius sp. & SA & EP \\
\hline & Chironomus riparius gr. & $\mathrm{N}$ & STP \\
\hline & Cladotanytarsus mancus gr. & $\mathrm{N}$ & STP \\
\hline & Corynoneura sp. & SA & TBP \\
\hline & Cricotopus bicinctus & $\mathrm{G}$ & TBP \\
\hline & Cricotopus sp. & $\mathrm{G}, \mathrm{SA}$ & EP, TBP \\
\hline & Cricotopus trifacia & SA & TBP \\
\hline & Dicrotendipes neomodestus & $\mathrm{N}$ & STP \\
\hline & Dicrotendipes nr. notatus & G & EP \\
\hline & Dicrotendipes sp. & SA, $N$ & TBP, STP \\
\hline & Einfeldia $\mathrm{sp}$ & SA & TBP \\
\hline & Glyptotendipes sp. gr. A & $\mathrm{N}$ & STP \\
\hline & Goeldichironomus holoprasinus & $\mathrm{N}$ & STP \\
\hline & Lauterborniella agrayloides & $\mathrm{G}$ & EP \\
\hline & Nanocladius rectinervis & SA & EP \\
\hline & Orthocladius sp. & $\mathrm{G}, \mathrm{SA}$ & EP, TBP \\
\hline & Parachironomus arcuatus gr. & $\mathrm{N}$ & STP \\
\hline & Parametriocnemus sp. & G & $\mathrm{EP}$ \\
\hline & Phaenopsectra sp. & $\mathrm{N}$ & STP \\
\hline & Polypedilum convictum & G & EP \\
\hline & Polypedilum illinoense & $\mathrm{N}$ & STP \\
\hline & Polypedilum sp. & SA & TBP \\
\hline & Pseudochironomus sp. & $\mathrm{G}, \mathrm{SA}$ & EP, TBP \\
\hline & Rheocricotopus fuscipes gr. & $\mathrm{G}, \mathrm{SA}$ & EP, TBP \\
\hline & Rheotanytarsus exiguus gr. & $\mathrm{G}, \mathrm{SA}$ & $\mathrm{EP}$ \\
\hline & Tanytarsus guerlus gr. & $\mathrm{G}, \mathrm{N}$ & EP, STP \\
\hline & Tanytarsus sp. & SA & $\mathrm{TBP}$ \\
\hline
\end{tabular}


Table 3. Aquatic invertebrates collected in streams of the South-Central Texas study unit, Texas-Continued

\begin{tabular}{|c|c|c|c|}
\hline $\begin{array}{l}\text { Class } \\
\text { Order } \\
\text { Family }\end{array}$ & Genus & $\begin{array}{l}\text { River } \\
\text { basin }\end{array}$ & Ecoregion \\
\hline \multicolumn{4}{|l|}{ Insecta (Hexopoda)-Continued } \\
\hline \multicolumn{4}{|l|}{ Diptera-Continued } \\
\hline \multirow[t]{4}{*}{ Chironomidae-Continued } & Thienemanniella $\mathrm{nr}$.xena & $\mathrm{SA}, \mathrm{N}$ & EP, STP \\
\hline & Thienemanniella sp. & SA & TBP \\
\hline & Thienemannimyia sp. & SA & TBP \\
\hline & Zavrelimyia sp. & SA & TBP \\
\hline Culicidae & Culex sp. & G & EP \\
\hline Empididae & Hemerodromia sp. & $\mathrm{G}, \mathrm{SA}, \mathrm{N}$ & EP, TBP, STP \\
\hline \multirow[t]{3}{*}{ Simuliidae } & Simulium nr. bivittatum & $\mathrm{N}$ & STP \\
\hline & Simulium nr. trivittatum & SA & EP \\
\hline & Simulium sp. & $\mathrm{G}, \mathrm{SA}, \mathrm{N}$ & EP, TBP \\
\hline Tabanidae & Tabanus sp. & G & $\mathrm{EP}$ \\
\hline \multirow[t]{3}{*}{ Tanypodinae } & Larsia sp. & G & EP \\
\hline & Natarsia punctata & $\mathrm{G}$ & $\mathrm{EP}$ \\
\hline & Pentaneura sp. & $\mathrm{G}$ & EP \\
\hline \multirow[t]{3}{*}{ Tipulidae } & Antocha sp. & SA & TBP \\
\hline & Geranomyia sp. & G & EP \\
\hline & Tipula sp. & SA & TBP \\
\hline \multicolumn{4}{|l|}{ Ephemeroptera } \\
\hline \multirow[t]{6}{*}{ Baetidae } & Baetis alius & SA & TBP \\
\hline & Baetis sp. & $\mathrm{N}$ & EP \\
\hline & Baetodes edmundsi & SA & $\mathrm{EP}$ \\
\hline & Baetodes sp. & G & TBP \\
\hline & Dactylobaetis mexicanus & $\mathrm{G}, \mathrm{SA}$ & EP, TBP \\
\hline & Fallceon quilleri & $\mathrm{G}, \mathrm{SA}, \mathrm{N}$ & EP, TBP, STP \\
\hline \multirow[t]{2}{*}{ Caenidae } & Caenis hilaris (Say) & $\mathrm{G}$ & $\mathrm{EP}$ \\
\hline & Caenis sp. & $\mathrm{G}, \mathrm{SA}, \mathrm{N}$ & EP, STP \\
\hline \multirow[t]{2}{*}{ Leptophlebiidae } & Thraulodes gonzalesi & $\mathrm{G}, \mathrm{SA}$ & EP, TBP \\
\hline & Traverella presidiana & $\mathrm{G}, \mathrm{SA}$ & EP, TBP \\
\hline Oligoneuriidae & Isonychia sicca manca & $\mathrm{G}, \mathrm{SA}$ & EP, TBP \\
\hline \multirow[t]{5}{*}{ Tricorythidae } & Leptohyphes packeri & $\mathrm{G}$ & TBP \\
\hline & Leptohyphes succinus & SA & $\mathrm{EP}$ \\
\hline & Leptohyphes vescus & SA & $\mathrm{EP}$ \\
\hline & Tricorythodes albilineatus gr. & $\mathrm{G}, \mathrm{SA}$ & EP, TBP \\
\hline & Tricorythodes curvatus gr. & SA & $\mathrm{EP}$ \\
\hline \multicolumn{4}{|l|}{ Hemiptera } \\
\hline Hebridae & Merragata sp. & $\mathrm{G}$ & EP \\
\hline Naucoridae & Ambrysus circumcinctus & $\mathrm{G}, \mathrm{SA}$ & EP, TBP \\
\hline \multicolumn{4}{|l|}{ Lepidoptera } \\
\hline \multirow[t]{2}{*}{ Pyralidae } & Parapoynx sp. & $\mathrm{G}$ & $\mathrm{EP}$ \\
\hline & Parargyractis sp. & $\mathrm{G}, \mathrm{SA}$ & EP, TBP \\
\hline \multicolumn{4}{|l|}{ Megaloptera } \\
\hline Corydalidae & Corydalus cornutus & SA & EP \\
\hline
\end{tabular}


Table 3. Aquatic invertebrates collected in streams of the South-Central Texas study unit, Texas-Continued

\begin{tabular}{|c|c|c|c|}
\hline $\begin{array}{l}\text { Class } \\
\text { Order } \\
\text { Family }\end{array}$ & Genus & $\begin{array}{l}\text { River } \\
\text { basin }\end{array}$ & Ecoregion \\
\hline \multicolumn{4}{|c|}{ Insecta (Hexopoda)—Continued } \\
\hline \multicolumn{4}{|c|}{ Odonata } \\
\hline Calopterygidae & Hetaerina sp. & $\mathrm{G}, \mathrm{SA}$ & $\mathrm{EP}$ \\
\hline \multirow[t]{6}{*}{ Coenagrionidae } & Argia bipunctulata & SA & TBP \\
\hline & Argia immunda (Hagen) & $\mathrm{G}$ & TBP \\
\hline & Argia sp. & $\mathrm{G}, \mathrm{SA}, \mathrm{N}$ & EP, TBP, STP \\
\hline & Argia translata Hagen & $\mathrm{G}, \mathrm{SA}, \mathrm{N}$ & EP, TBP \\
\hline & Enallagma sp. & $\mathrm{G}$ & TBP \\
\hline & Ischnura sp. & $\mathrm{N}$ & STP \\
\hline Gomphidae & Erpetogomphus sp. & $\mathrm{G}$ & TBP \\
\hline Libellulidae & Brechmorhoga mendax & $\mathrm{G}, \mathrm{SA}$ & EP, TBP \\
\hline \multicolumn{4}{|l|}{ Trichoptera } \\
\hline Calamoceratidae & Phylloicus ornatus & G & $\mathrm{EP}$ \\
\hline Ecnomidae & Austrotinodes texensis & SA & $\mathrm{EP}$ \\
\hline \multirow[t]{2}{*}{ Glossosomatidae } & Protoptila alexanderi & $\mathrm{G}$ & $\mathrm{EP}$ \\
\hline & Protoptila sp. & G & TBP \\
\hline \multirow[t]{2}{*}{ Helicopsychidae } & Helicopsyche borealis & G & EP \\
\hline & Helicopsyche piroa Ross & $\mathrm{G}, \mathrm{SA}$ & EP, ТВP, ЕСТP \\
\hline Hydrobiosidae & Atopsyche erigia Ross & $\mathrm{G}$ & EP, ЕCTP \\
\hline \multirow[t]{9}{*}{ Hydropsychidae } & Cheumatopsyche comis & G & $\mathrm{EP}$ \\
\hline & Cheumatopsyche pettiti & $\mathrm{G}$ & $\mathrm{EP}$ \\
\hline & Cheumatopsyche sp. & $\mathrm{G}, \mathrm{SA}, \mathrm{N}$ & EP, TBP \\
\hline & Hydropsyche bidens & $\mathrm{N}$ & $\mathrm{EP}$ \\
\hline & Hydropsyche orris & $\mathrm{G}$ & EP \\
\hline & Hydropsyche simulans & $\mathrm{G}, \mathrm{SA}, \mathrm{N}$ & EP, TBP \\
\hline & Hydropsyche sp. & $\mathrm{G}, \mathrm{SA}$ & $\mathrm{EP}$ \\
\hline & Smicridea fasciatella & $\mathrm{G}, \mathrm{SA}, \mathrm{N}$ & EP, STP \\
\hline & Smicridea $\mathrm{sp}$ & $\mathrm{G}, \mathrm{SA}, \mathrm{N}$ & EP, TBP \\
\hline \multirow[t]{15}{*}{ Hydroptilidae } & Hydroptila ajax & $\mathrm{G}$ & $\mathrm{EP}$ \\
\hline & Hydroptila angusta & G & $\mathrm{EP}$ \\
\hline & Hydroptila melia & G & TBP \\
\hline & Hydroptila protera & $\mathrm{N}$ & $\mathrm{EP}$ \\
\hline & Hydroptila sp. & $\mathrm{G}, \mathrm{SA}, \mathrm{N}$ & EP, TBP, STP \\
\hline & Hydroptila waubesiana & $\mathrm{G}$ & $\mathrm{EP}$ \\
\hline & Leucotrichia sarita Ross & G & $\mathrm{EP}$ \\
\hline & Leucotrichia sp. & G & ТВP \\
\hline & Mayatrichia nr. ayama & SA & $\mathrm{EP}$ \\
\hline & Mayatrichia nr. ponta & SA & $\mathrm{EP}$ \\
\hline & Neotrichia edalis Ross & G & $\mathrm{EP}$ \\
\hline & Neotrichia sp. & $\mathrm{G}, \mathrm{SA}$ & EP, TBP \\
\hline & Neotrichia vibrans Ross & $\mathrm{G}$ & TBP \\
\hline & Ochrotrichia nigritta & G & $\mathrm{EP}$ \\
\hline & Ochrotrichia sp. & $\mathrm{G}, \mathrm{SA}, \mathrm{N}$ & EP, TBP \\
\hline
\end{tabular}


Table 3. Aquatic invertebrates collected in streams of the South-Central Texas study unit, Texas-Continued

\begin{tabular}{|c|c|c|c|}
\hline $\begin{array}{l}\text { Class } \\
\text { Order } \\
\text { Family }\end{array}$ & Genus & $\begin{array}{l}\text { River } \\
\text { basin }\end{array}$ & Ecoregion \\
\hline \multicolumn{4}{|l|}{ Insecta (Hexopoda)-Continued } \\
\hline \multicolumn{4}{|l|}{ Trichoptera-Continued } \\
\hline \multirow[t]{5}{*}{ Hydroptilidae-Continued } & Ochrotrichia tarsalis & G & $\mathrm{EP}$ \\
\hline & Oxyethira azteca (Mosely) & $\mathrm{G}$ & $\mathrm{EP}$ \\
\hline & Oxyethira pallida (Banks) & $\mathrm{G}$ & $\mathrm{EP}$ \\
\hline & Oxyethira sp. & $\mathrm{G}, \mathrm{SA}, \mathrm{N}$ & EP, TBP \\
\hline & Oxyethira ulmeri & $\mathrm{G}, \mathrm{N}$ & $\mathrm{EP}$ \\
\hline \multirow[t]{8}{*}{ Leptoceridae } & Nectopsyche gracilis & G & EP, TBP \\
\hline & Nectopsyche pavida & G & TBP \\
\hline & Nectopsyche sp. & $\mathrm{G}, \mathrm{SA}$ & TBP \\
\hline & Oecetis avara & $\mathrm{G}, \mathrm{SA}$ & EP, TBP \\
\hline & Oecetis inconspicua & $\mathrm{G}$ & $\mathrm{EP}$ \\
\hline & Oecetis persimilis & $\mathrm{G}, \mathrm{N}$ & EP \\
\hline & Oecetis sp. & $\mathrm{G}, \mathrm{SA}$ & $\mathrm{EP}$ \\
\hline & Triaenodes ignitus & G & EP \\
\hline \multirow[t]{5}{*}{ Philopotamidae } & Chimarra beameri & $\mathrm{N}$ & $\mathrm{EP}$ \\
\hline & Chimarra feria & G & $\mathrm{EP}$ \\
\hline & Chimarra obscura & $\mathrm{G}$ & $\mathrm{EP}$ \\
\hline & Chimarra sp. & $\mathrm{G}, \mathrm{SA}, \mathrm{N}$ & EP, TBP \\
\hline & Chimarra texana & $\mathrm{G}$ & $\mathrm{EP}$ \\
\hline \multirow[t]{3}{*}{ Polycentropodidae } & Polycentropus sp. & SA & $\mathrm{EP}$ \\
\hline & Polyplectropus charlesi & G & TBP \\
\hline & Polyplectropus proditus & $\mathrm{G}, \mathrm{SA}$ & EP \\
\hline Nematoda & & $\mathrm{G}$ & $\mathrm{EP}$ \\
\hline Nemertea & Prostoma rubrum & $\mathrm{G}, \mathrm{SA}$ & EP, TBP \\
\hline \multicolumn{4}{|l|}{ Oligochaeta } \\
\hline \multicolumn{4}{|l|}{ Haplotaxida } \\
\hline Enchytraeidae & N/D & $\mathrm{N}$ & STP \\
\hline Glossoscolecidae & Sparganophilus tamesis & $\mathrm{G}, \mathrm{SA}$ & EP \\
\hline Naididae & Slavina appendiculata & $\mathrm{G}, \mathrm{SA}$ & EP \\
\hline \multirow[t]{3}{*}{ Tubificidae } & Branchiura sowerbyi & $\mathrm{G}, \mathrm{SA}$ & EP, TBP \\
\hline & Limnodrilus hoffmeisteri & $\mathrm{N}$ & STP \\
\hline & Limnodrilus sp. & $\mathrm{G}, \mathrm{N}$ & EP, STP \\
\hline Lumbriculidae & $\mathrm{N} / \mathrm{D}$ & SA & TBP \\
\hline \multicolumn{4}{|l|}{ Pelecypoda (Bivalvia) } \\
\hline Corbiculidae & Corbicula fluminea & $\mathrm{G}, \mathrm{SA}, \mathrm{N}$ & EP, TBP, STP \\
\hline \multirow[t]{3}{*}{ Sphaeriidae } & Eupera cubensis & $\mathrm{G}$ & $\mathrm{EP}$ \\
\hline & Musculium sp. & SA & TBP \\
\hline & Pisidium nitidum & $\mathrm{G}$ & $\mathrm{EP}$ \\
\hline \multicolumn{4}{|l|}{ Tubellaria } \\
\hline \multicolumn{4}{|l|}{ Tricladida } \\
\hline \multirow[t]{2}{*}{ Planariidae } & Dugesia tigrina & $\mathrm{G}, \mathrm{SA}$ & EP, TBP \\
\hline & Phagocata sp. & SA & $\mathrm{TBP}$ \\
\hline
\end{tabular}


Table 4. Aquatic macrophytes in aquatic habitats of the South-Central Texas study unit, Texas

[From Lemke (1989)]

\begin{tabular}{|c|c|c|c|}
\hline $\begin{array}{l}\text { Division } \\
\text { Family }\end{array}$ & Genus & $\begin{array}{l}\text { Division } \\
\text { Family }\end{array}$ & Genus \\
\hline Anthophyta & & Anthophyta-Continued & \\
\hline Acanthaceae & Hygrophila lacustris & Onagraceae & Ludwigia repens \\
\hline Alismataceae & Sagittaria platyphylla & Poaceae & Zizania texana \\
\hline Araceae & Pistia stratiotes & Pontederiaceae & Eichhornia crassipes \\
\hline Ceratophyllaceae & Ceratophyllum demersum & & Heteranthera liebmannii \\
\hline \multirow[t]{3}{*}{ Haloragaceae } & Myriophyllum brasiliense & Potamogetonaceae & Potamogeton crispus \\
\hline & Myriophyllum hererophyllum & & Potamogeton illinoensis \\
\hline & Myriophyllum spicatum & & Potamogeton nodosus \\
\hline \multirow[t]{3}{*}{ Hydrocharitaceae } & Egeria densa & & Potamogeton pectinatus \\
\hline & Hydrilla verticillata & Scrophulariaceae & Limnophila sessiflora \\
\hline & Vallisneria americana & Zannichelliaceae & Zannichellia palustris \\
\hline \multirow[t]{3}{*}{ Lemnaceae } & Lemna minor & Bryophyta & \\
\hline & Spirodela polyrhiza & Hypnaceae & Amblystegium riparium \\
\hline & Wolffia papulifera & Ricciaceae & Riccia fluitans \\
\hline Lentibulariaceae & Utricularia gibba & Pterophyta & \\
\hline Najadaceae & Najas guadalupensis & Parkeriaceae & Ceratopteris thalictroides \\
\hline \multirow[t]{2}{*}{ Nymphacaceae } & Cabomba caroliniana & Salviniaceae & Azolla caroliniana \\
\hline & Nuphar luteum & & \\
\hline
\end{tabular}

Table 5. Non-native species in aquatic habitats of the South-Central Texas study unit, Texas

[From Bowles and Arsuffi (1993); Howells (1997); and U.S. Fish and Wildlife Service (1995). --, not known or not applicable]

\begin{tabular}{|c|c|c|c|}
\hline $\begin{array}{l}\text { Phylum (division) } \\
\text { Family }\end{array}$ & Genus & Common name & Mechanism of introduction \\
\hline \multicolumn{4}{|l|}{ Anthophyta } \\
\hline \multirow[t]{2}{*}{ Araceae } & Colocasia esculenta & Wild taro & -- \\
\hline & Pistia stratiotes & Water lettuce & -- \\
\hline \multirow[t]{2}{*}{ Haloragaceae } & Myriophyllum brasiliense & Parrotfeather & aquaria \\
\hline & Myriophyllum spicatum & Eurasian watermilfoil & aquaria \\
\hline \multirow[t]{2}{*}{ Hydrocharitaceae } & Egeria densa & Giant waterweed & aquaria \\
\hline & Hydrilla verticillata & African elodea & aquaria \\
\hline Pontederiaceae & Eichhornia crassipes & Water hyacinth & ornamental \\
\hline Potamogetonaceae & Potamogeton crispus L. & Curly pondweed & -- \\
\hline Scrophulariaceae & Limnophila sessiflora & -- & aquaria \\
\hline \multicolumn{4}{|l|}{ Chordata } \\
\hline \multirow[t]{3}{*}{ Centrarchidae } & Ambloplites rupestris & Rock bass & game fish \\
\hline & Lepomis auritus & Redbreast sunfish & game fish \\
\hline & Micropterus dolomieu & Smallmouth bass & game fish \\
\hline Characidae & Astyanax mexicanus & Mexican tetra & -- \\
\hline \multirow[t]{4}{*}{ Cichlidae } & Cichlasoma cyanoguttatum & Rio Grande cichlid & pond fish \\
\hline & Tilapia aurea & Blue tiliapia & aquaria \\
\hline & Tilapia mossambica & Mozambique tilapia & aquaria \\
\hline & Tilapia zilli & Redbelly tilapia & aquaria \\
\hline \multirow[t]{3}{*}{ Cyprinidae } & Carassius auratus & Goldfish & aquaria \\
\hline & Ctenopharyngodon idella & Grass carp & plant control \\
\hline & Cyprinus carpio & Common carp (koi) & pond fish \\
\hline
\end{tabular}


Table 5. Non-native species in aquatic habitats of the South-Central Texas study unit, Texas-Continued

\begin{tabular}{|c|c|c|c|}
\hline $\begin{array}{l}\text { Phylum (division) } \\
\text { Family }\end{array}$ & Genus & Common name & Mechanism of introduction \\
\hline \multicolumn{4}{|l|}{ Chordata-Continued } \\
\hline Cyprinodontidae & Cyprinodon variegatus & Sheepshead minnow & bait \\
\hline \multirow[t]{2}{*}{ Loricariidae } & Hypostomus plecostomus & Suckermouth catfish & aquaria \\
\hline & Myocastor coypus & Nutria & fur production \\
\hline Percichthyidae & Morone saxatilis & Striped bass & game fish \\
\hline Percidae & Stizostedion vitreum & Walleye & game fish \\
\hline \multirow[t]{3}{*}{ Poeciliidae } & Poecilia formosa & Amazon molly & bait/aquaria \\
\hline & Poecilia latipinna & Sailfin molly & bait \\
\hline & Poecilia reticulata & Guppy & aquaria \\
\hline \multirow[t]{3}{*}{ Salmonidae } & Oncorhynchus mykiss & Rainbow trout & game fish \\
\hline & Salmo trutta & Brown trout & game fish \\
\hline & Salvelinus fontinalis & Brook trout & game fish \\
\hline \multicolumn{4}{|l|}{ Mollusca } \\
\hline Ampullariidae & Marisa cornuarietis & Giant ramshorn snail & aquaria \\
\hline Corbiculidae & Corbicula fluminaea & Asiatic clam & -- \\
\hline \multirow[t]{2}{*}{ Thiaridae } & Melanoides granifera & Quilted Melania & aquaria \\
\hline & Melanoides tuberculata & Red-rimmed melania & aquaria \\
\hline \multicolumn{4}{|l|}{ Pterophyta } \\
\hline Parkeriaceae & Ceratopteris thalictroides & Water sprite & aquaria \\
\hline $\begin{array}{l}\text { Order } \\
\text { family }\end{array}$ & Genus & Common name & Mechanism of introduction \\
\hline \multicolumn{4}{|l|}{ Rodentia } \\
\hline Myocastoridae & Myocastor coypus & Nutria & fur production \\
\hline
\end{tabular}

Table 6. Federal and State listed endangered and threatened species in aquatic habitats of the South-Central Texas study unit, Texas

[From Campbell (1995); U.S. Fish and Wildlife Service (1997). E, endangered; T, threatened]

\begin{tabular}{|c|c|c|c|c|}
\hline $\begin{array}{l}\text { Phylum (division) } \\
\text { Family }\end{array}$ & Genus & Common name & Federally listed & State listed \\
\hline \multicolumn{5}{|l|}{ Anthophyta } \\
\hline Gramineae & Zizania texana & Texas wild rice & $\mathrm{E}$ & \\
\hline \multicolumn{5}{|l|}{ Arthropoda } \\
\hline Crangonyctidae & Stygobromus pecki & Peck's cave amphipod & $\mathrm{E}$ & \\
\hline Dryopidae & Stygoparnus comalensis & Comal Springs dryopid beetle & $\mathrm{E}$ & \\
\hline Elmidae & Heterelmis comalensis & Comal Springs riffle beetle & $\mathrm{E}$ & \\
\hline \multicolumn{5}{|l|}{ Chordata } \\
\hline Catostomidae & Cycleptus elongatus & Blue sucker & & $\mathrm{T}$ \\
\hline \multirow[t]{2}{*}{ Ictaluridae } & Satan eurystomus & Widemouth blindcat & & $\mathrm{T}$ \\
\hline & Trogloglanis pattersoni & Toothless blindcat & & $\mathrm{T}$ \\
\hline Microhylidae & Hypopachus variolosus & Sheep frog & & $\mathrm{T}$ \\
\hline Percidae & Etheostoma fonticola & Fountain darter & $\mathrm{E}$ & $\mathrm{E}$ \\
\hline \multirow[t]{5}{*}{ Plethodontidae } & Eurycea latitans & Cascade Caverns salamander & & $\mathrm{T}$ \\
\hline & Eurycea nana & San Marcos salamander & $\mathrm{T}$ & $\mathrm{T}$ \\
\hline & Eurycea tridentifera & Comal blind salamander & & $\mathrm{T}$ \\
\hline & Typhlomolge rathbuni & Texas blind salamander & $\mathrm{E}$ & $\mathrm{E}$ \\
\hline & Typhlomolge robusta & Blanco blind salamander & & $\mathrm{E}$ \\
\hline Poeciliidae & Gambusia georgei & San Marcos gambusia & $\mathrm{E}$ & $\mathrm{E}$ \\
\hline
\end{tabular}


Table 7. Troglobitic species of the Edwards aquifer in the South-Central Texas study unit, Texas

[From Bowles and Arsuffi (1993); Longley (1986)]

\begin{tabular}{|c|c|c|c|}
\hline \multirow{2}{*}{$\begin{array}{l}\text { Class } \\
\text { Order }\end{array}$} & \multicolumn{3}{|c|}{ Class } \\
\hline & Genus & Order & Genus \\
\hline Family & \multicolumn{3}{|c|}{ Family } \\
\hline Turbellaria & & Crustacea-Continued & \\
\hline Tricladida & & Isopoda & \\
\hline \multirow[t]{4}{*}{ Planariidae } & Sphalloplana kutscheri & Asellidae & Asellus pilus \\
\hline & Sphalloplana mohri & & Asellus redelli \\
\hline & Sphalloplana sloani & & Lirceolus smithi \\
\hline & Sphalloplana zeschi & Cirolanidae & Cirolanides texensis \\
\hline Ostracoda & & Thermosbaenacea & \\
\hline Podocopida & & Monodellidae & Monodella texana \\
\hline Cypridopsidae & Cypridopsis vidua obesa & Gastropoda & \\
\hline Entocytheridae & Sphaeromicola moria & Mesogastropoda & \\
\hline Copepoda & & Hydrobiidae & Balconorbis uvaldensis \\
\hline Harpacticoida & & & Phreatodrobia conica \\
\hline \multirow[t]{3}{*}{ Cyclopidae } & Cyclops cavernarum & & Phreatodrobia imitata \\
\hline & Cyclops learii & & Phreatodrobia micra \\
\hline & Cyclops varicans rebellus & & Phreatodrobia nugax inclinata \\
\hline Crustacea & & & Phreatodrobia nugax nugax \\
\hline Amphipoda & & & Phreatodrobia plana \\
\hline Artesiidae & Artesia subterranea & & Phreatodrobia punctata \\
\hline Bogidiellidae & Parabogidiella americana & & Phreatodrobia rotunda \\
\hline \multirow[t]{5}{*}{ Crangonyctidae } & Stygobromus balconis & & Stygopyrgus bartonensus \\
\hline & Stygobromus bifurcatus & Insecta (Hexopoda) & \\
\hline & Stygobromus flagellatus & Coleoptera & \\
\hline & Stygobromus pecki & Dryopidae & Stygoparnus comalensis \\
\hline & Stygobromus russelli & Dytiscidae & Hadeoporus texanus \\
\hline \multirow[t]{4}{*}{ Hadziidae } & Allotexiweckelia hirsuta & Osteichthyes & \\
\hline & Texiweckelia insolita & Siluriformes & \\
\hline & Texiweckelia samacos & Ictaluridae & Satan eurystomus \\
\hline & Texiweckelia texensis & & Trogloglanis pattersoni \\
\hline Sebidae & Seborgia relicta & Amphibia & \\
\hline Decapoda & & Caudata & \\
\hline \multirow[t]{2}{*}{ Palaemonidae } & Palaemonetes antrorum & Ambystomidae & Typhlomolge (Eurycea) rathbuni \\
\hline & Palaemonetes holthuisi & & Typhlomolge (Eurycea) robusta \\
\hline
\end{tabular}


District Chief

U.S. Geological Survey

8027 Exchange Dr.

Austin, TX 78754-4733 